\title{
Francesco Patrizi's two books on space: geometry, mathematics, and dialectic beyond Aristotelian science
}

\author{
Amos Edelheit

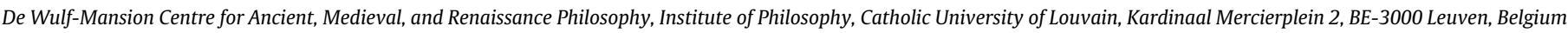

\section{A R T I C L E I N F O}

Keywords:

Francesco Patrizi

Space

Geometry

Mathematics

Aristotle

Proclus

\begin{abstract}
A B S T R A C T
Francesco Patrizi was a competent Greek scholar, a mathematician, and a Neoplatonic thinker, well known for his sharp critique of Aristotle and the Aristotelian tradition. In this article I shall present, in the first part, the importance of the concept of a three-dimensional space which is regarded as a body, as opposed to the Aristotelian two-dimensional space or interval, in Patrizi's discussion of physical space. This point, I shall argue, is an essential part of Patrizi's overall critique of Aristotelian science, in which Epicurean, Stoic, and mainly Neoplatonic elements were brought together, in what seems like an original theory of space and a radical revision of Aristotelian physics. Moreover, I shall try to show Patrizi's dialectical method of definition, his geometrical argumentation, and trace some of the ideas and terms used by him back to Proclus' Commentary on Euclid. This text of Proclus, as will be shown in the second part of the article, was also important for Patrizi's discussion of mathematical space, where Patrizi deals with the status of mathematics and redefines some mathematical concepts such as the point and the line according to his new theory of space.
\end{abstract}

(c) 2009 Elsevier Ltd. All rights reserved.

When citing this paper, please use the full journal title Studies in History and Philosophy of Science

In the present study I shall present the importance of the concept of a three-dimensional space which is regarded as a body, as opposed to the Aristotelian two-dimensional space or interval, in Patrizi's discussion of physical and mathematical space. This point, I shall argue, is an essential part of Patrizi's overall critique of Aristotelian science, in which Epicurean, Stoic, and mainly Neoplatonic elements were brought together, in what seems like an original theory of space and a radical revision of Aristotelian physics. More- over, I shall try to show Patrizi's dialectical method of definition, his geometrical argumentation, the status he gives to mathematics and his reasons for it, and trace some of the ideas and terms used by him back to Proclus' Commentary on Euclid. ${ }^{1}$

Francesco Patrizi of Cherso (1529-1597) is well known for his sharp critique of Aristotle and the Aristotelian tradition. ${ }^{2}$ Thus, for instance, he was not willing to accept even Aristotelian logic as an important novelty of the Stagirite, claiming in the second part

\footnotetext{
E-mail address: amos.edelheit@hiw.kuleuven.be

1 As already shown by Deitz (1999), p. 155, Patrizi's idea that space is body comes directly from Proclus, whose doctrines are cited by Simplicius in his Corollarium de loco, in

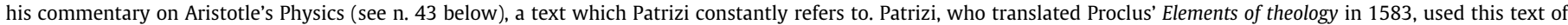

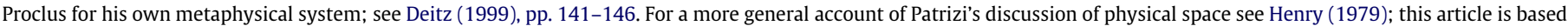

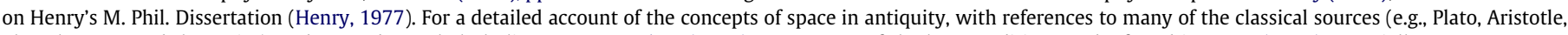

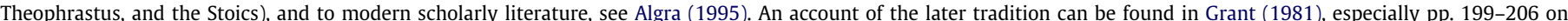

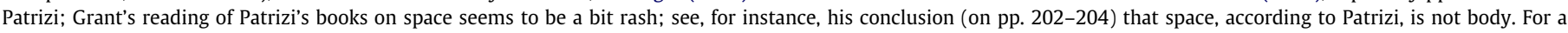
detailed discussion of the concepts of place and space in medieval philosophy, and mainly in Peter Auriol, see Schabel (2000).

2 Patrizi was by no way unique in the philosophical context of the sixteenth century in his criticism and rejection of Aristotle; but one should be careful with regard to any

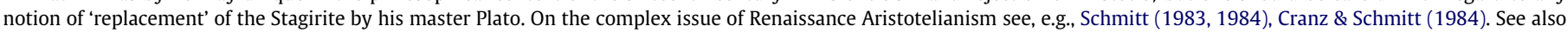

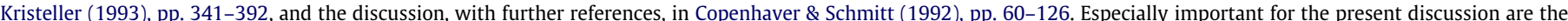

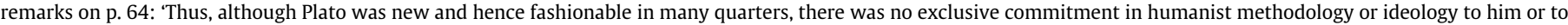

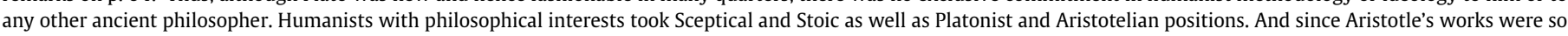

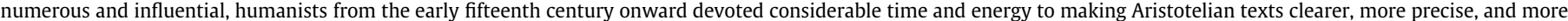
readable'. See also Bianchi $(2003,2007)$.
} 
of his Discussiones peripateticae of 1581 that Aristotle said nothing new even in the field of logic. ${ }^{3}$ What about physics and mathematics? He dedicated two books, which were published separately in 1587 (entitled De rerum natura, libri duo priores. Alter de Spacio Physico, Alter de Spacio Mathematico), and then incorporated into his opus magnum, Nova de universis philosophia, published twice, in 1591 and in 1593, to the concept of physical and mathematical space; this topic, which although (as specifically mentioned by Patrizi) it was not part of the Aristotelian corpus, is also used by him to criticize contemporary Aristotelian philosophers in a rhetorical-methodological remark at the beginning of his discussion of physical space. ${ }^{4}$ It has been necessary to make this remark - which we shall shortly expand since Patrizi seems to present here the importance of what he regarded as a completely new concept: the concept of space.

In the first book, on physical space, Patrizi reconstructs the physical reality of the cosmos (and in fact, this section of his work is entitled Pancosmia), its status and the relations between its different components on different levels of corporeal and incorporeal being. He begins by pointing out, through a series of rhetorical questions, that the existence of space (spacium) is the foundation of everything else, its existence enables the existence of all other levels of being: space is the first thing that God created, it is the first being which is independent of, and superior to, all other beings, and without which nothing exists. ${ }^{5}$ It is important to note the essential connection between existence and space: being, according to Patrizi, is related to, or determined by, a space, which ensures existence. Thus, since the grades of reality exist, they exist somewhere, in a place or a space which is beyond them and superior to them. This means that existence is now related to either two or three dimensions: length, breadth, or depth. ${ }^{6}$ At this stage Patrizi uses the terms locus and spacium as synonyms, but as we shall see, he will later distinguish between them in his hierarchy of beings in the physical cosmos. ${ }^{7}$ We can already notice Patrizi's geometrical point of view, or as he himself puts it at the very beginning of his work, the geometrical necessities which are included among the ways he uses to prove his philosophy. ${ }^{8}$

But if the concept of space is indeed so important, Patrizi should now explain (thus anticipating future criticisms by contemporary Aristotelians) how it has been omitted in Aristotelian science, and more specifically, Aristotelian physics. To this end, he addresses the following methodological assertion:

Some 'friends' of ours from the Peripatos, when they had read [these] two books on space which were composed by me, delightfully insulted me, since their own leader never wrote anything of this sort. They certainly are ridiculous and stupid human beings, and [also] ignorant of their own leader's writings. Indeed, what else is a place for him [Aristotle], other than a long and wide space? Although in a place [there is] depth, which is more properly a [characteristic of] a place, he [Aristotle] ridiculously said nothing about it. What else is magnitude for him [Aristotle], upon which every [kind of] movement, upwards, downwards, sideways or in circle, takes place for him? Do they not believe that between earth and heaven, there is space? But let us just leave them [the Aristotelians], who, since Aristotle said nothing about the new orbit, they do not allow themselves to be persuaded that there is a new orbit. Let us philosophize [by using] other intellects than those, let us use the testimonies of the senses and the proofs of arguments. Let us not be terrified by any great names. Let us investigate the things themselves, the truth in things, and the causes of truth. Let us search for the truth, for the sake of truth. ${ }^{9}$

Patrizi is clearly distancing himself from the Aristotelian physics which he no doubt knows very well. He is introducing the concept of space as the basis for a new physics, which should be proved by both sense perception and reason, in search for the true structure of reality. His references to Aristotle need some clarification: what does he mean by saying that the Aristotelians do not know well enough the writings of their own leader when they argue that Aristotle did not deal with the concept of space? And if they are indeed wrong in this and he does discuss this concept, what then is the basis of Patrizi's criticism of Aristotle? The terms

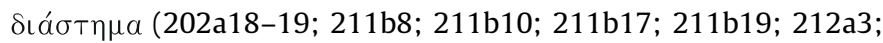
212a11; 213a28; 213a32; 214a5-6; 214a9-10; 214a20; 214a30;

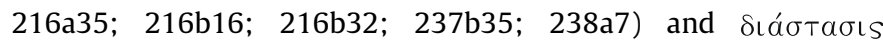
(202b18-19) for instance, which are translated as spacium in the Latin translations of Aristotle's Physics, obviously attracted Patrizi's attention. But Aristotle of course never comes close to Patrizi's

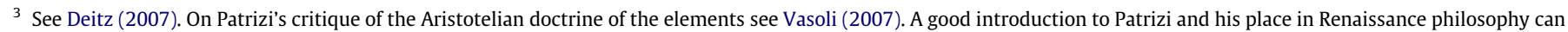
be found in Kristeller (1966) pp. 110-126, with notes on pp. 175-177.

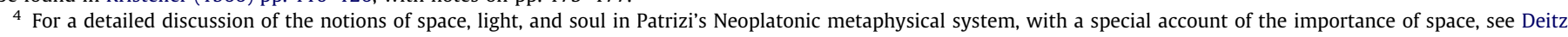

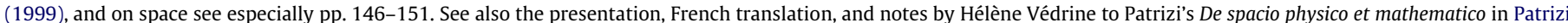

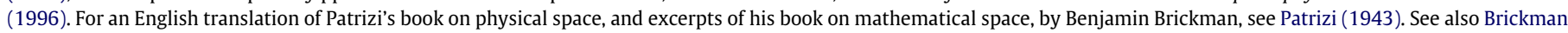
(1941). For references to most of the modern scholarly discussions of Patrizi's life, works, and philosophy, see Deitz (1999), pp. 158-159 nn. 3, 7.

5 Patrizi (1591), fol. 61 ${ }^{\text {r: ' }}$ Quod autem illud fuit, quod summus opifex primum omnium extra se produxit? Quid aut debuit, aut expedijt prius producit, quam id quo omnia alia,

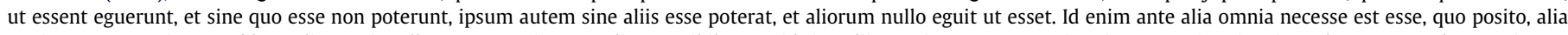

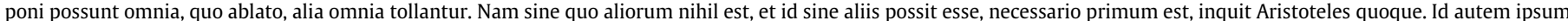

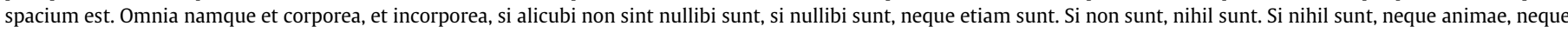

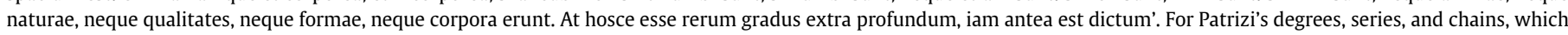

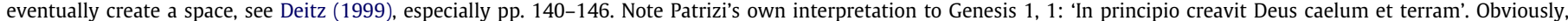
according to Patrizi, God created the space which separates heaven from earth. This becomes very clear in his methodological remark cited and discussed in n. 9 below.

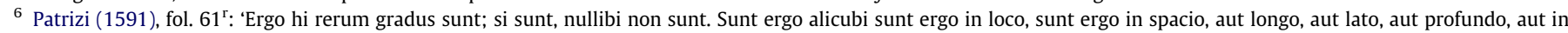
duobus horum, aut in tribus. Spacium ergo ante haec omnia est. Et eo illa ut sint indigent, ipsum vero, ut sit, illorum indiget nullo'.

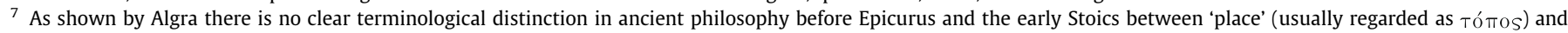
'space' (usually regarded as $\chi \omega ́ \rho \alpha)$. See Algra (1995), pp. 31-71.

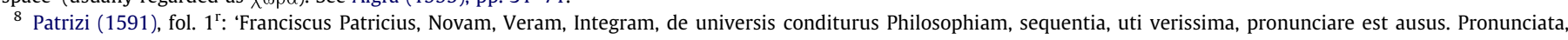

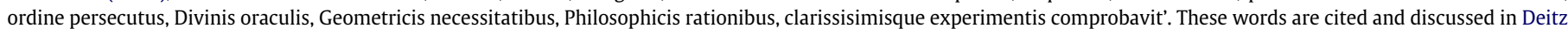

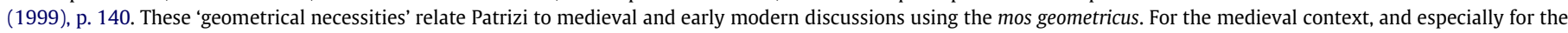
Liber de causis and its influence, see Lohr (1986); see also Tummers (1980). For the early modern context see, e.g., Garber (1995).

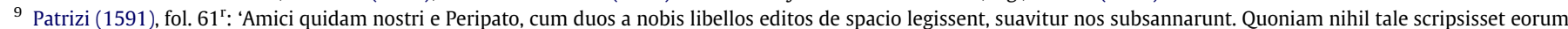

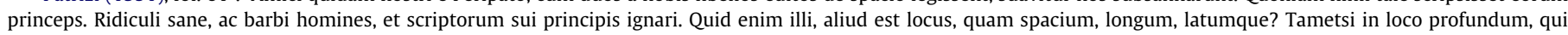

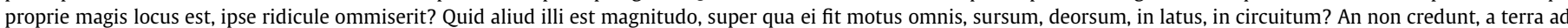

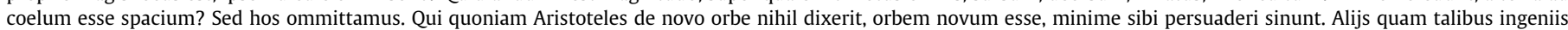

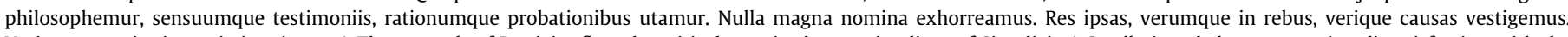

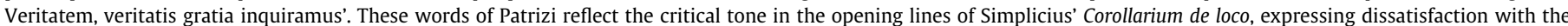

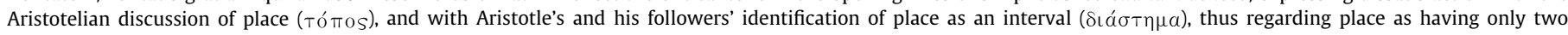

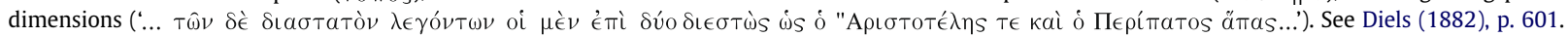


notion of space. ${ }^{10}$ Space is never at the centre of Aristotle's discussion, and the very basic notions of vacuum and movement are totally different according to Patrizi.

After stating that bodies, forms, and qualities are all intimately related to space, ${ }^{11}$ Patrizi claims that the soul and its three parts are connected to space as well: the sensitive part is distributed throughout the body; with regard to the other two (which he calls ratio and mens), if indeed they provide the forms of the body, then they are extended through bodies just like other forms. Patrizi is again criticizing Aristotle on this point, claiming that if the soul is in the body, it is not there as forma (a form), but rather as formatrix (the element which forms). ${ }^{12}$ The word formatrix is not classical and is rather rare in medieval texts. It is probable that Patrizi is reflecting here something which he found in his Greek Neoplatonic sources. Terms such

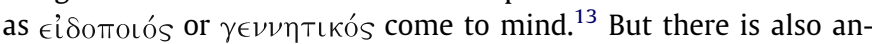
other possibility. The active role given to the soul here can be compared with the active role given to the soul in creating mathematical concepts by Proclus in his commentary on Euclid, which is also a critique of the Aristotelian notion of direct abstraction from matter or sense perception as the process through which mathematical concepts are formed. ${ }^{14}$ The Latin word formatrix which refers to the soul in Patrizi's discussion, can be regarded as an echo of Barozzi's se ipsum producit, et a proprio producitur principio, et vita seipsum explet, $a b$ opificeque sine corpore, ac sine dimensione expletur. In the Greek

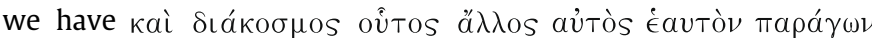

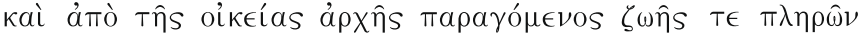

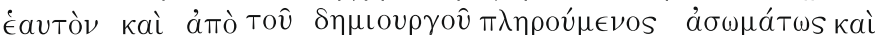

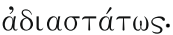

Patrizi seems to neglect the distinction between material and immaterial substances while dealing with physical space: space, the first and superior being which is body, is essentially connected to all other beings through their corporeality. Every being is thus redefined according to its relation to space. He is using a probabilistic method of dialectical definition according to which every hypothetical possibility (either negative or positive) is related to space. In this way space becomes the first absolute being to which all other beings are related:

But if indeed the body were in the soul, if this [soul] would be divisible, it will be in divisible space. If [this soul] were indivisible, it will be in indivisible space. But if the whole of divinity were indivisible, as is the case, it will be in indivisible space, and it will be covered all around by divisible space. Likewise, if [divinity] were nowhere, it would not be thinkable without space; if it were somewhere, either at the top of heaven or above heaven, it will certainly be in space. If indeed [divinity] were everywhere, it cannot not be in space. Therefore, all beings, and those things which are above beings, are in space. And they cannot not be in space. Accordingly, before beings came out of the depth, they required space, by which depth itself was surrounded, so that they would come out of the depth, and would endure, if at all beings should or could exist. And thus space flowed from the first one, before all other beings, and it is blown and dispersed in the finite and in the infinite as by the breath of its mouth. Therefore, we should no longer examine whether space exists in the wholeness of things, but rather explore whether space is something. ${ }^{15}$

We can notice the rhetorical power of Patrizi's arguments which refer to both ontological and epistemological levels. It is also remarkable how Patrizi combines physics and cosmology on the one hand, and theology on the other, while discussing the relations between space and divinity.

In dealing with the question whether space would be something, Patrizi begins by mentioning the different terms for space which he found in his Latin and Greek sources, immediately moving on to describe some 'proofs' for the existence of space based on sense perception. ${ }^{16}$ Then, he strongly connects space and existence, by arguing, through a presentation of several rhetorical questions

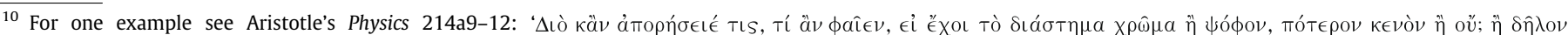

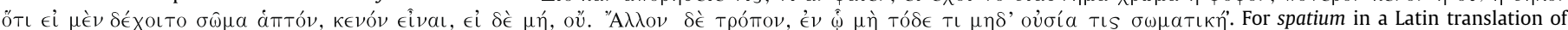

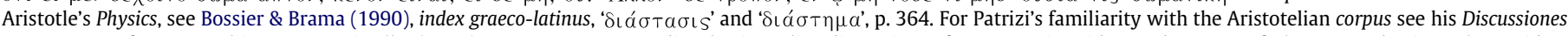

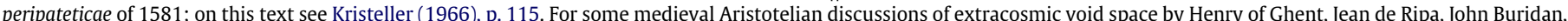

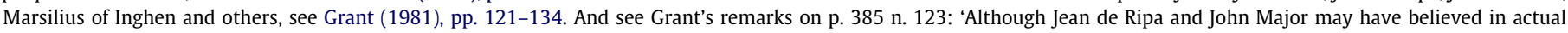

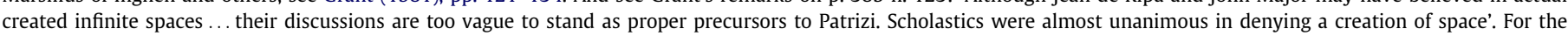

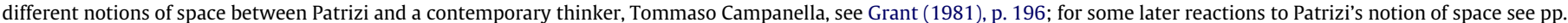
206-213.

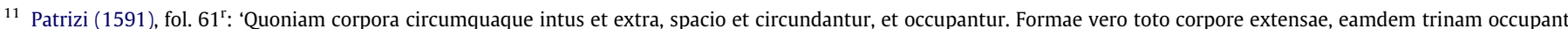

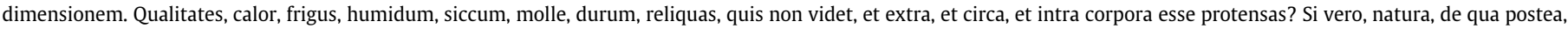
per corpora, et ipsa protensa esse reperiatur, et eorum externa attingere, et interna habitare, ipsa quoque in spacio esse erit dicenda'.

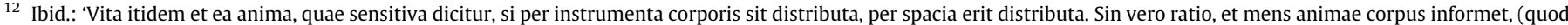

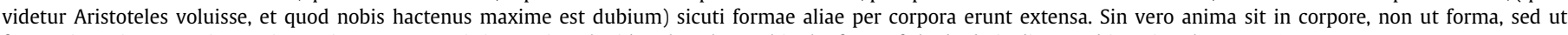
formatrix, quia corpus in spacio est, ipsa quoque erit in spacio'. The idea that the soul is the form of the body is discussed in Aristotle's De anima 414a4-14.

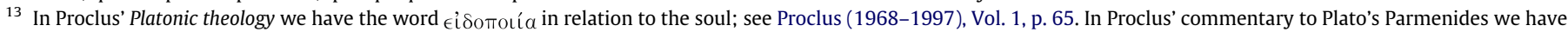

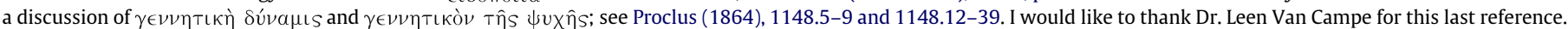

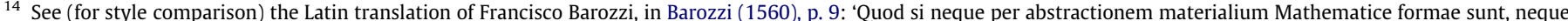

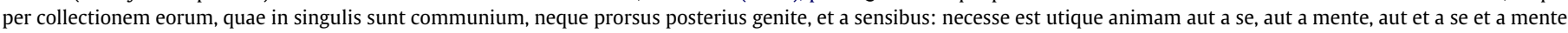

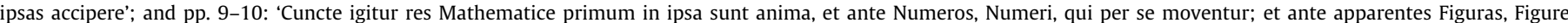

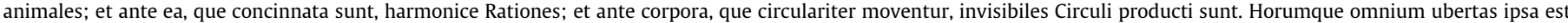

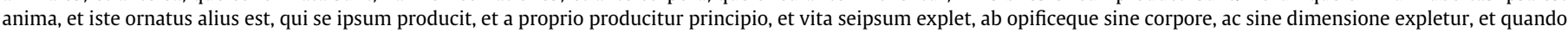

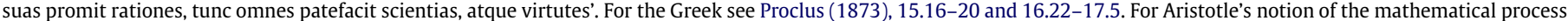
see, e.g., Metaphysics 1059b6-16.

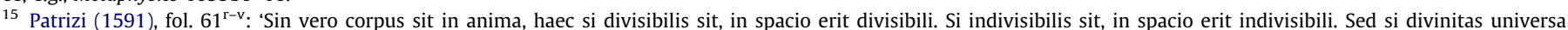

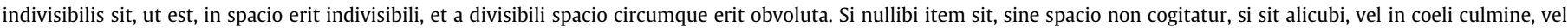

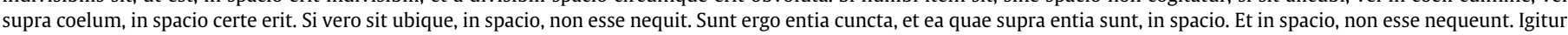

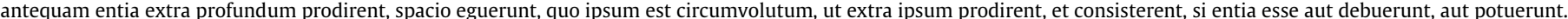

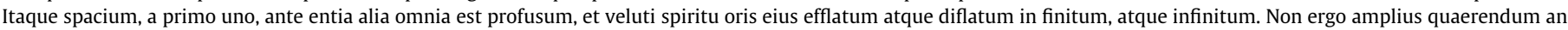

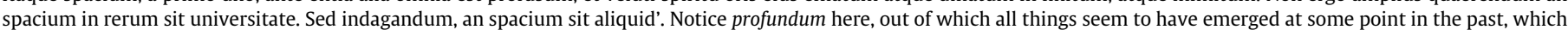
could be a combination of the Hebrew of Gen 1,1, which Jerome translates as terra... inanis et vacua, and the $\chi \hat{\omega} \rho a$ of the Platonic Timaeus.

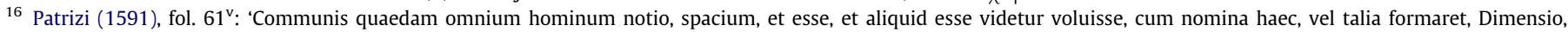

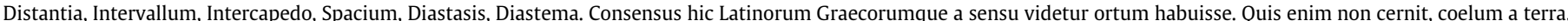

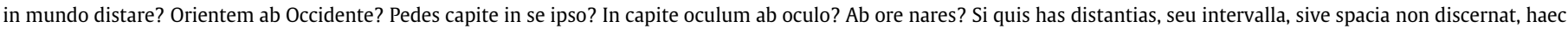
legere, aut intelligere, non laboret'.
} 
regarding being and not being, that if something is, it is being (si est aliquid, ens est). ${ }^{17}$

Next, Patrizi moves on to describe what sort of a thing space is. Here we find for the first time in the discussion of space his geometrical point of view. Patrizi, following the ancients (veteres), distinguishes between three spaces: length, represented by a line; breadth, represented by a surface; and depth, which together with the other two spaces they called a body. ${ }^{18}$ Then, following the mathematicians, he regards length without breadth as the first space or interval; breadth as the second; and depth as the third. Moreover, Patrizi contends, these three spaces cannot be regarded separately: they are connected to each other and dependent upon one another; and through this connection body is formed. ${ }^{19}$ Following the philosophers of nature, Patrizi regards the natural body as containing not only the three former spaces (length, breadth, and depth), but also resistance. ${ }^{20}$ We can find these three spaces in all separate bodies, either mathematical or natural, which are perceived by both mind and senses. ${ }^{21}$ It is important to notice that for Patrizi the notion of space is not abstract but very concrete, and so both the mind and the senses can grasp it without any difficulty. As we shall see, mathematics is the science of space, through which we can have a more detailed knowledge about space and everything which is in space; we do not need mathematics in order to prove the existence of space: we know it through our mind and feel it through our senses.

Patrizi regards also qualities as corporeal matters, through which space and its three parts are extended. While space creates bodies, bodies or parts of them contain qualities. ${ }^{22}$ Bodies and qualities are thus instruments of space through which it extends. The difference between bodies and qualities is that while space is essential in bodies, it is only accidental in qualities; it means that qualities are completely dependent for their very existence upon bodies and space, without which there can be no qualities. ${ }^{23}$ It is important to notice that everything in the physical cosmos described by Patrizi is defined according to space and according to its position in space.
As we shall see, also mathematics as a science is determined according to space, since it is regarded as the science of space par excellence. This means again no separation between an ontological and an epistemological level.

Before going on to the next question Patrizi makes an interesting remark regarding his method of demonstration. Obviously he does not use scholastic syllogisms, but rather regards what he has just presented as sermone demonstratum. ${ }^{24}$ Without putting too much emphasis on the term sermo, we can say that by using it here Patrizi is relating himself to the humanist philosophers and to the humanists in general, who emphasized the power and importance of speech and rhetoric (artes sermonales). This does not mean that Patrizi uses rhetoric without reasonings, or precise definitions of terms; it only means that his notion of demonstration is flexible, and that he is aware of the different ways and levels of demonstration, presentation, and persuasion in a philosophical and scholarly discourse.

The next question deals with the ontological independence of space, or whether there is some other space beyond that which we find inside single bodies. ${ }^{25}$ In order to prove the existence of space outside bodies Patrizi introduces another term: place (locus), which is different from body. It contains the same three spaces (length, breadth, and depth), but still it is not body. ${ }^{26}$ What is it then?

Therefore a place, since it is not a body, by necessity it will be a space which is provided with triple dimension, length, breadth, and depth, through which it would gain for itself and take hold of length, breadth, and depth of the placed body. And such triple space is a real place, a different [space] from the placed [space of the body], immovable by itself, and wheresoever turned towards, it is like the placed body. A place then has its own space, which is other than the particular space of a body. ${ }^{27}$

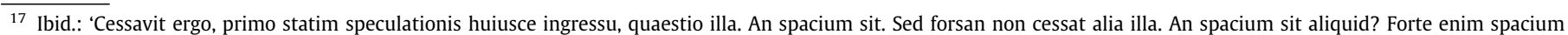

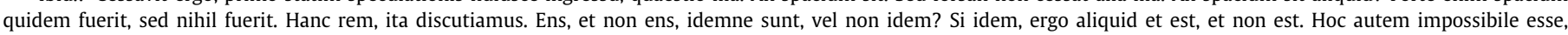

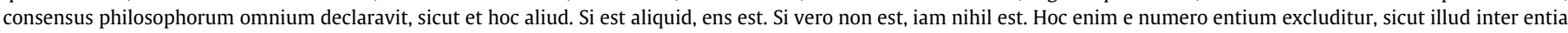

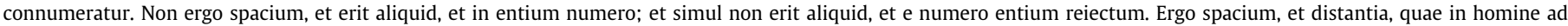
pedes est; de numero entium est, et est aliquid. Et ita de ceteris intervallis quibuscunque'. On this see Deitz (1999), p. 148 , and p. 163 n. 46.

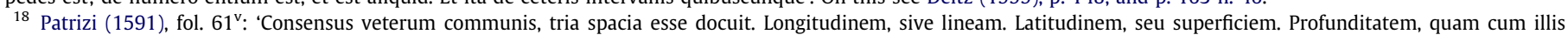
duabus vocaverunt corpus'.

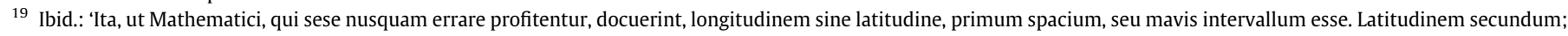

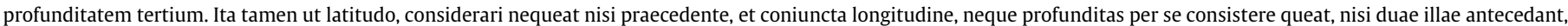

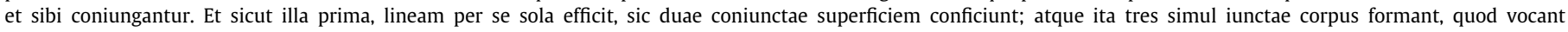
mathematicum'.

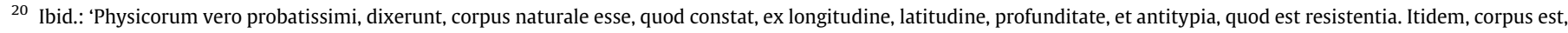
quod habet tres diastases (hoc est distantias) cum antitypia'.

21 Ibid.: 'In corporibus ergo singulis, qualiacumque illa sint, vel mathematica, vel naturalia, spacia tria reperiuntur, quae et mente, et sensu percipiuntur'.

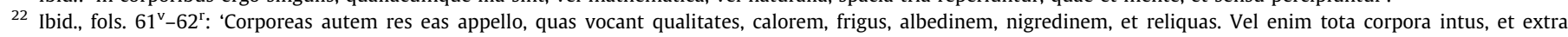

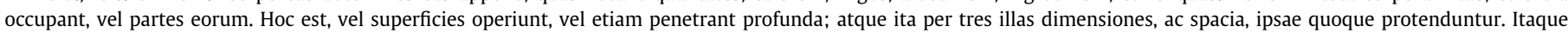
concludemus, dimensiones has, atque distantias, et per eas, spacium simpliciter, in corporeis rebus, hoc est, per corpora protensis, reperiri sicuti in corporibus ipsis'.

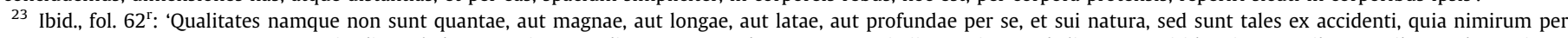

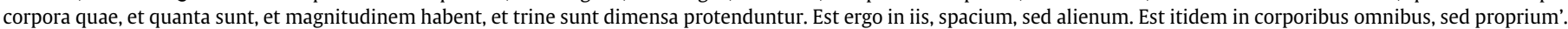

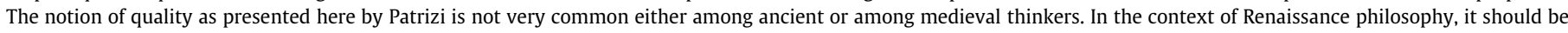

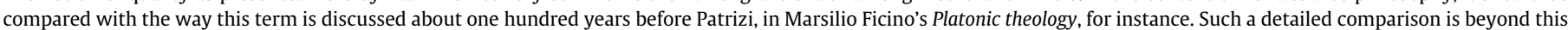

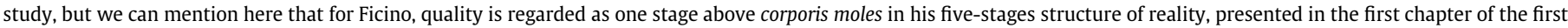

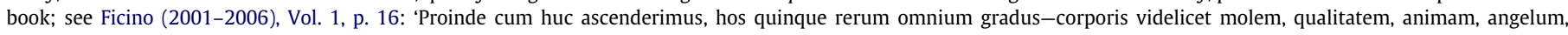

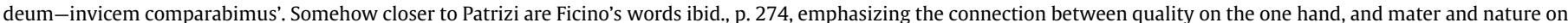

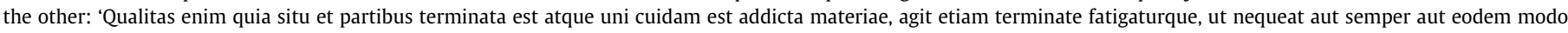

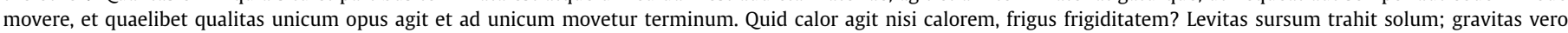

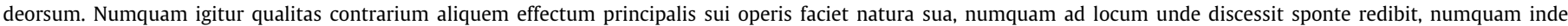
discedet sponte quo se naturaliter contulit'. See also Muccillo (1986), especially pp. 670-671.

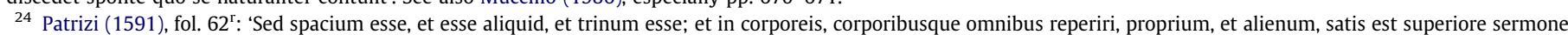
demonstratum'.

25 Ibid.: 'an ullum sit aliud spacium, quam quod singulis inest corporibus'.

26 Ibid.: 'Locus ergo tria spacia habet, quae habet omne corpus, et tamen locus non est corpus'.

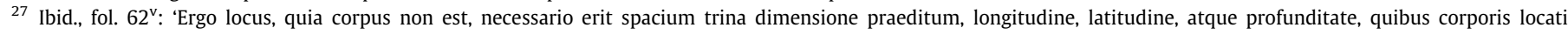

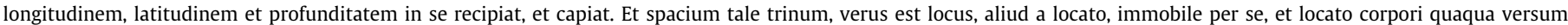

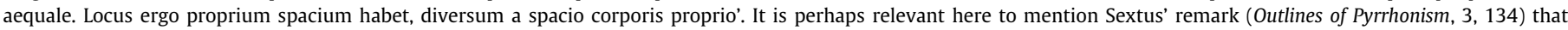

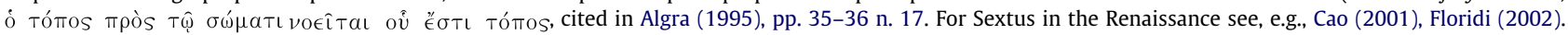


A place is thus a three-dimensioned space and it comes before body in the order of nature. ${ }^{28}$ In the same order, as we have seen, body comes before quality.

Thus, in Patrizi's physical space, quality is added to body, body is placed in a place, and a place is in fact a space which is filled with body. A vacuum is defined as an empty place or a space without body which contains the same three dimensions: length, breadth, and depth. Basically, Patrizi stresses, vacuum, space, plenum, and place are the same. ${ }^{29}$ After presenting what he regards as experiments, together with arguments, showing the existence of vacuum, ${ }^{30}$ Patrizi concludes that sense perception, experimental knowledge, and reason, all show the existence of empty spaces in the world. ${ }^{31}$ And what about outside the world? Also there, our philosopher claims, there is an empty space, and the authority of Aristotle are not valid enough to refute it; but then, how will it be possible to prove such an idea? Sense perception cannot help us, neither can any authority among the ancients. Here, Patrizi suggests that we should use sound or intelligent reasons (rationes sensatae). ${ }^{32}$ These kind of reasons help us to prove a hypothetical assumption that there is an empty space outside the world, where no sense perception can reach, and although Aristotle's arguments are against such a possibility, it is important to notice that the ontological structure of reality (the existence of empty space outside the world) determines our epistemological instruments (sound or intelligent reasons). Thus, the Ram of the zodiac has, according to the astrologers, a certain length and breadth which is in the inmost surface of heaven, or in the profound body of heaven, and in the internal mass; but why, Patrizi asks, would this surface not be continuous, and correspond with the most remote and extreme surface of the same heaven as well? It is necessary that heaven as a body should have a surface, upon which are the lengths and breadths of the signs of the zodiac (which can be bigger and smaller than the Ram), and such a contiguous surface requires bigger and bigger space which is empty. If, Patrizi contends, from the beginning and the end of each sign lines are drawn all the way towards both poles through the same surface of heaven, an image of a pumpkin is created, which these lines divide into twelve equal parts. It is necessary that each of these parts shall have just as many continuous parts of empty space. And so, it is necessary that the whole heaven and world should be surrounded by an outermost space. ${ }^{33}$

Ratio sensata is, then, according to Patrizi, taking some assumptions from an accepted theory, say in astrology (without proving them or declaring that they are correct or valid), through which we can start a critical examination of a thesis or an idea (the existence of an empty space surrounding the world) which is beyond the senses and against most authorities; this examination includes looking for consistency in the overall cosmic picture which is derived from these assumptions, and looking for a hidden assumption which can connect this cosmic picture with the thesis under discussion (in this case, the existence of a continuous surface of heaven which requires an empty space). Once again we notice that the cosmic picture described here by Patrizi is that of a geometrical cosmos which contains bodies, lines, surfaces, places, and spaces. This ratio sensata is totally clear, and if someone still has some doubts, Patrizi says, it is evident that something is wrong with his eyes and mind. ${ }^{34}$ But if someone would like to know more about this issue, Patrizi immediately introduces the first among three references in his discussion of the physical space to a known Stoic the-

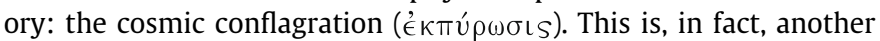
ratio sensata which shows the existence of an empty space surrounding the world: if the world is going to end up in vapors or smoke, then it will occupy a much bigger place. ${ }^{35}$ And here we come back to the idea of an empty space:

But this place would be that empty space, that when a body refills it, it will be called a place, but now since no body fills it, it is only an empty space. And they perceived this idea by means of thought, those who introduced this dogma, not different from that abstraction, which other natural philosophers use in the thinking out of [their] doctrines. And just as there is nothing absurd following on these [ideas], so also on this speculation of the conflagration nothing absurd follows. ${ }^{36}$

We have here exactly the same structure of the ratio sensata we have seen before, in the discussion of the Ram.

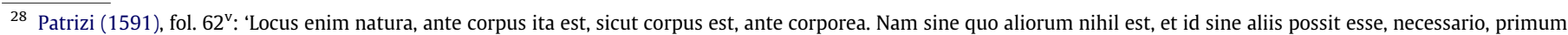
est'. It is important to notice that Patrizi uses here the same formulation he used earlier with regard to space. See n. 5 above.

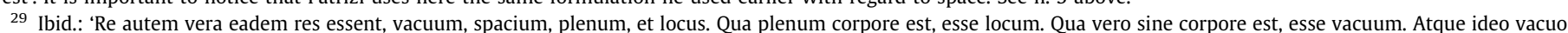

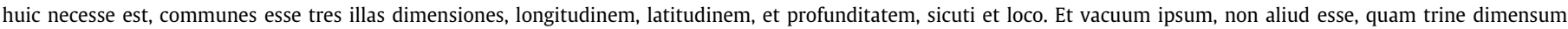
spacium'.

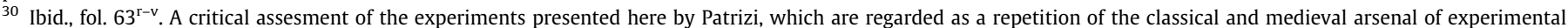
evidence rather than anything close to the seventeenth-century new scientific approach, can be found in Schmitt (1981), VII. And see also Deitz (1999), p. 164 n. 51.

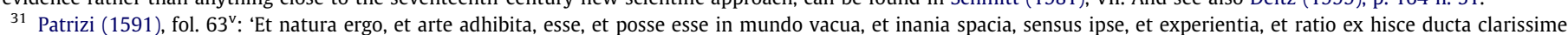
demonstravit'.

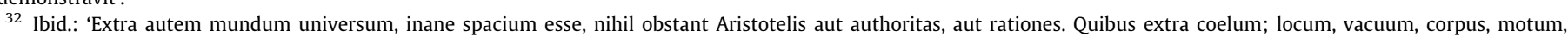

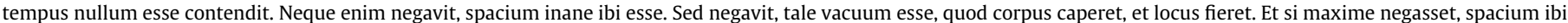

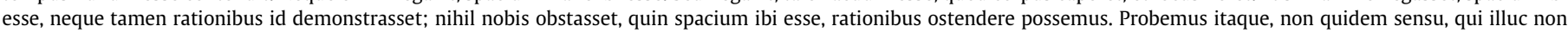

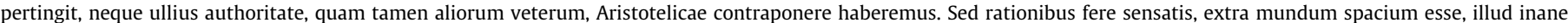

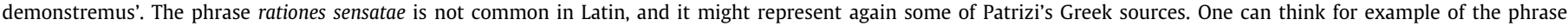

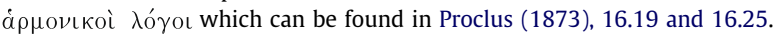

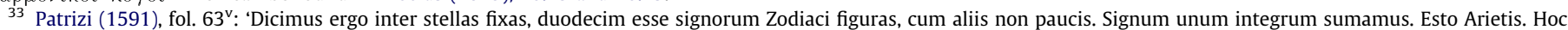

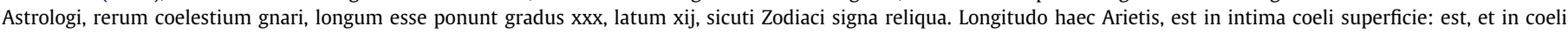

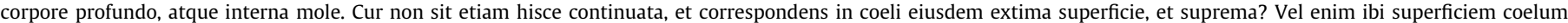

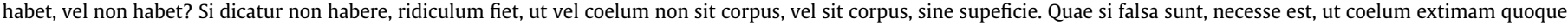

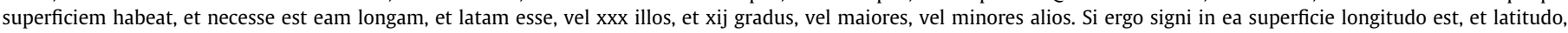

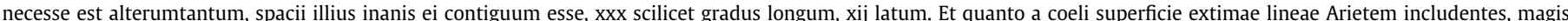

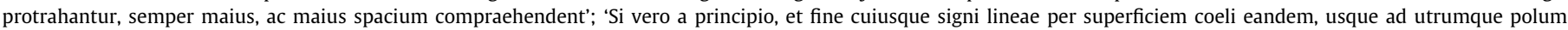

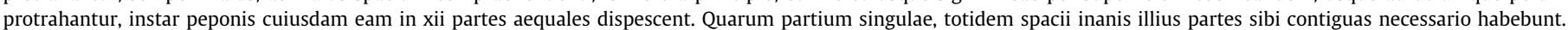
Atque ita universum coelum, ac mundus universus extimo spacio circundabitur necessario'.

34 Ibid.: 'Quae res ita clara modo facta est, ut si quis de ea dubitet amplius, dubitem an compos oculorum, et mentis fiet'.

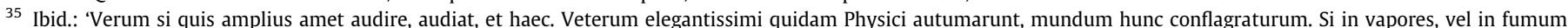

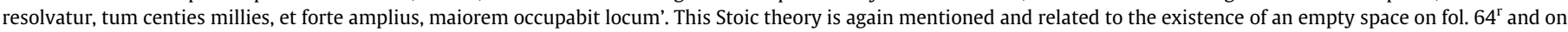

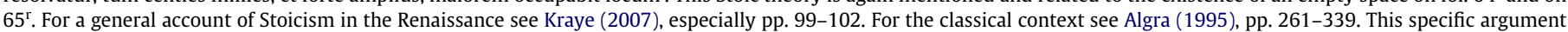

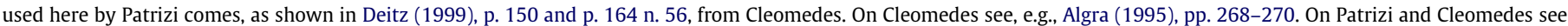
Todd (1982).

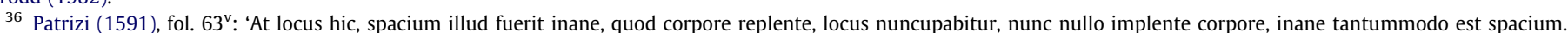

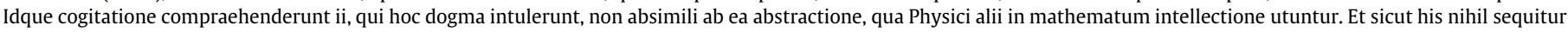
absurdum, ita illi cogitationi conflagrationis, absurdi sequetur nihil'.
} 
Another kind of argument used by Patrizi can be regarded as a thought experiment: if the whole world can be considered by the mind as being moved from its place, then, this is further evidence for the existence of that empty space around it. ${ }^{37}$ This may also be a ratio sensata, but different from the two we have just seen.

Moving on to some historical account of ancient opinions (most of them taken from the Stoics) concerning empty external space, and whether it is finite, infinite, or just the biggest among all things, ${ }^{38}$ Patrizi chooses to follow his own path, using again his geometrical point of view:

While proceeding through another path we say that the space which is outside the world is both finite and infinite. It is indeed finite on that side which touches the most remote surface of the world. Indeed, [this side has no] special and natural limit of its own, but only the world's boundary. But in that [side] in which [space] is separated from the world, and it is far departed from it, it becomes infinite. ${ }^{39}$

Here we have another example of Patrizi's flexible notions and his rejection of dichotomies, according to which the same thing can be finite on one level, and infinite on another level. On a logical level this is of course impossible. But in Patrizi's geometrical cosmos and its ontological and epistemological structure, there is no contradiction: space can be absolutely finite on the side which touches the world, or with regard to the comprehension of our mind, and still be absolutely infinite in its nature. ${ }^{40}$

This conceptual flexibility enables Patrizi to begin his distinction between the four different parts or levels of the physical space: empty space (spacium inane), place (locus), body (corpus), and quality (qualitas). The last three are contained in the world (mundus), which is another term used by Patrizi. The only difference between empty space and place-space is that place-space sets the world, it is full of the world's body, while empty space is empty of any kind of body. This means that, as we have already seen, empty space is both finite and infinite, while place-space is only finite. ${ }^{41}$ Here we have the starting point of an accidental hierarchy between these levels of physical space. Patrizi stresses that the fact that place-space is full of body is only accidental and does not belong to its essence, which is being empty or a vacuum. While the spaces of bodies are accidental with regard to the nature of place-space, and their essential properties consist of resistance, the essence of place-space belongs to vacuum. ${ }^{42}$ Here, so it seems, we already have an essential hierarchy or distinction between the spaces of bodies and place-space. This was probably true in an Aristotelian framework, and since Patrizi just used the terms 'accidental' and 'essential', one can be misled. Things are even more confusing if we remember that space itself, according to Patrizi (following Proclus) is body. ${ }^{43}$ Our philosopher should clarify the relations between emptiness/fullness, and non-resistance/resistance, in regard to different kinds of bodies-spaces.

According to Patrizi, due to the fact that half of the mundane space and the whole of the outside space are empty, space can contain bodies without any resistance, it divides all bodies and is divided by them, and it cannot damage or be damaged by any body. ${ }^{44}$ In determining the relation between space and bodies Patrizi again shows his conceptual flexibility, suggesting a completely different framework from the Aristotelian one. Thus, space is not similar to bodies, but it is also not contrasted to, or opposed by, bodies. It cannot resist them, it applies itself to them. Space shares with the bodies its points, lines, surfaces, and depths, and it is by no means deprived of them, but rather both space and bodies contain and hold each other, penetrate, grasp and determine each other. ${ }^{45}$ Patrizi ends this description with a series of rhetorical questions which reveal his dialectical method and some potential sources:

Since indeed [space] would both produce and support all these things [bodies], and it would offer [itself] to all bodies, so that they would exist, act, [and] endure, why should it not be called the principle [or the beginning] of every essence, act, and enduring of bodies? And since [space] would enclose all bodies, why would it not likewise be regarded as the boundary [or end] of bodies? And hence, [why should space] not in like manner be declared to be both the origin and the end of things? And since [space] would be both finite and infinite, why should it not be

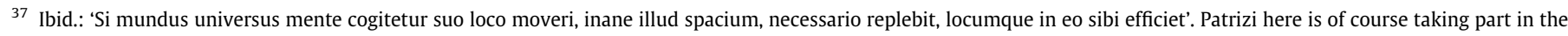

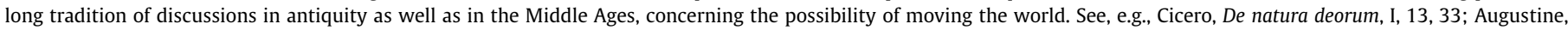
Sermones, L, 10; Thomas Aquinas, Summa theologiae, I, q. 103, a. 1.

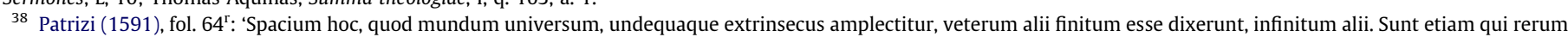

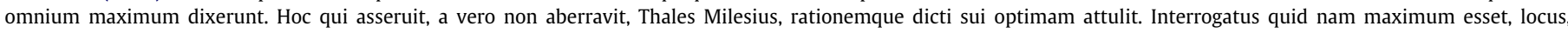

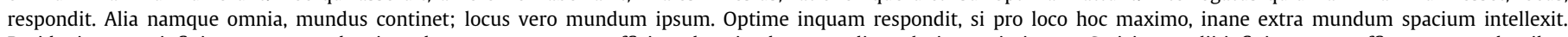

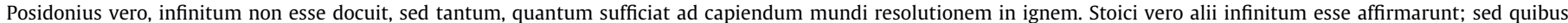
rationibus id confirmarunt, nequaquam constat'. For some of the ancient sources see Diels \& Kranz (1969), Vol. 1, p. 71; Edelstein \& Kidd (1972), Frag. 84 and 97a-b.

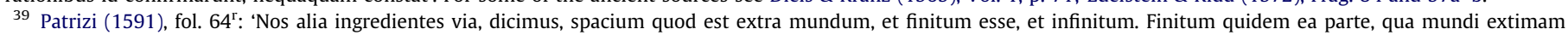
superficiem contingit; non quidem proprio, et naturali fine suo, sed mundi terminis. Qua vero digreditur a mundo, ab eoque procul abit, in infinitum transit'.

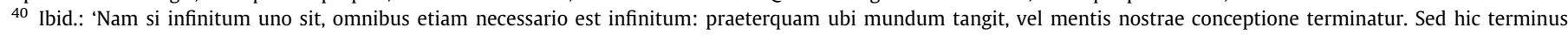
naturam eius non mutat, nec ab infinitate sua dimovet'.

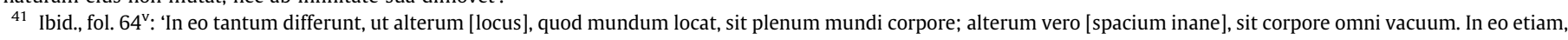
differt hoc ab illo, quod illud, et finitum est, et infinitum, hoc autem totum est finitum'.

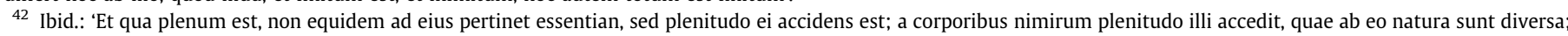

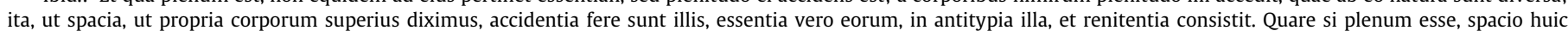

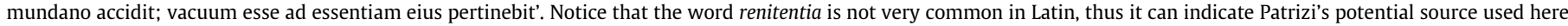
as well as his originality.

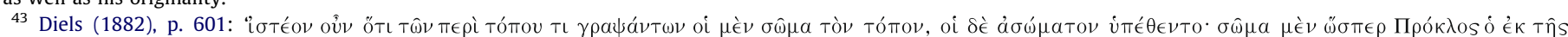

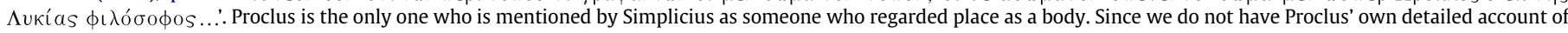

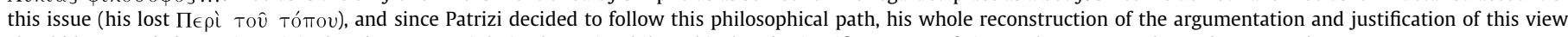
should be regarded as quite original and new, certainly in the Latin philosophical and scientific context of sixteenth-century Italy. And see n. 4 above.

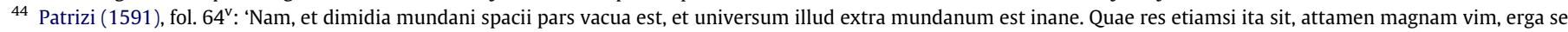

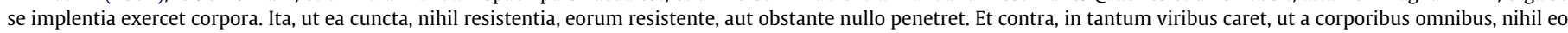
prorsus renitente penetretur. Dividat etiam corpora omnia: et a corporibus omnibus dividatur. Nullum corpus laedat, a nullo corpore laedatur'.

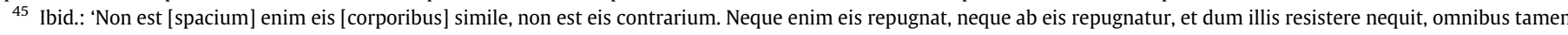

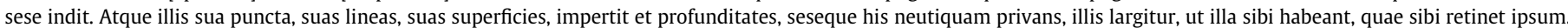

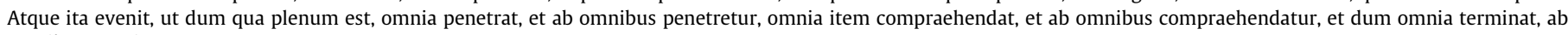
omnibus terminetur'.
} 
called the origin and the end with regard to finite and infinite matters, many of which things the most distinguished among the ancients said, or probably wanted to say. ${ }^{46}$

The word principium which I translated as principle, beginning,

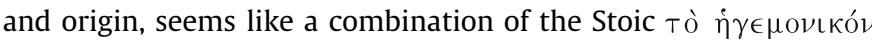
(which is usually translated by Calcidius and Seneca as principale, and by Cicero as principatum) and the Neoplatonic Tò $\tilde{\epsilon} \nu$, although the materiality of the Stoic notion is more relevant to Patrizi's discussion of space, which is in any case, with regard to the ancient sources, quite original. ${ }^{47}$ Patrizi's last remark shows that he was aware of its provenance: not being able to mention specific authorities, he just refers to the intention of some most distinguished ancients.

With regard to the relation between corporeal qualities and bodies, Patrizi argues that these qualities are definitely inferior to bodies, and should be regarded as accidents, while bodies are substances. ${ }^{48}$ But places are superior to bodies, since otherwise, Patrizi contends, bodies would not be in a place, which is impossible according to all the philosophers. ${ }^{49}$ In summing up the relations between corporeal qualities, bodies, places, and empty space, Patrizi stresses the superiority of place to qualities and bodies both in nature and in time. By its nature, place, before becoming a place, that is becoming full of bodies, was part of the empty space. This means that the empty space precedes the place by nature. And here again the ontological and the epistemological level are combined: emptiness or vacuum (the special property of space) precedes both in nature (natura) and in thought (cogitatione) the state of being full (the special property of place) ${ }^{50}$

It is only at this point that Patrizi fully presents his cosmos of four entities. There are no other entities in nature besides space, place, body, and quality, he contends, determining again the hierarchy between them, from the lowest (quality) to the highest (space), and yet mentioning another term, the world, a general term which contains places, bodies, and qualities, but is obviously inferior to space, which is the first entity among everything which is in the universe. ${ }^{51}$ It is important to stress again the connection made by Patrizi between space and being: nothing can exist without being somewhere, and being somewhere means for Patrizi being in a place-space. This is essential since it enables our philosopher now to move from the discussion of different spaces (empty space, placespace, body-space) to the discussion of different entities (entia) in the cosmic hierarchy. And as we shall see, these entities or substances should not be understood in an Aristotelian framework: Patrizi rejects both Aristotelian physics and Aristotelian logic.

In order to show the preexistence of space to world Patrizi uses again the Stoic doctrine of cosmic conflagration: the assumption underlying this idea is, according to Patrizi, the preexistence of an empty space in which the world, while existing, is placed; this space, as long as it is the place of the world, is of course a placespace, but it immediately becomes an empty space in the case of a total destruction of the world. And this empty space is the basis of, or the physical pre-condition for, or the starting point of, a new creation of the world by God. In other words Patrizi is presenting here space's active role in the process of creation. The only authorities mentioned here by Patrizi are many wise men who were inspired by a divine spirit. ${ }^{52}$ This means, he continues, that God created this empty space before creating the world we inhabit. In his description of what was going on in this empty space before the creation of the world, Patrizi leaves the Stoics and uses some typical Epicurean concepts. ${ }^{53}$

Now we can come back to the essential question: what is space? Patrizi is of course dealing with different aspects of this question since the beginning of the book, and loyal to his dialectical method he will now try to present better answers, taking into account the conclusions of his previous discussions.

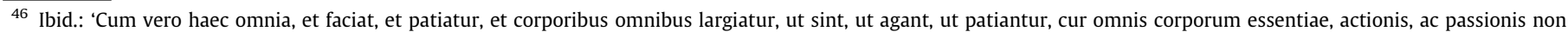

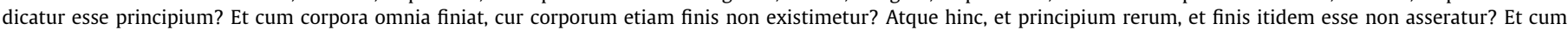
finitum, et infinitum sit, cur, et principium, et finis, finita, et infinita non dicentur? Quorum pleraque praestantissimi veterum dixere, vel forte dicere voluere'.

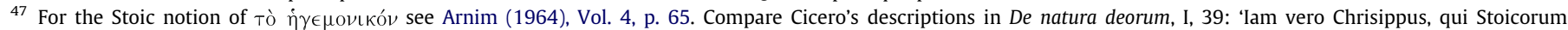

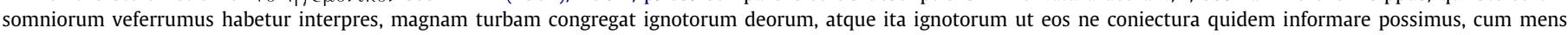

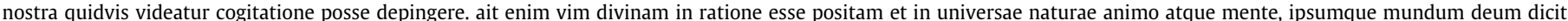

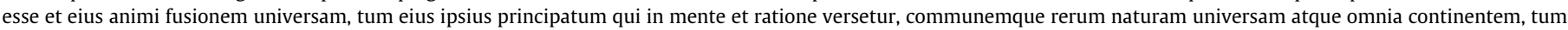

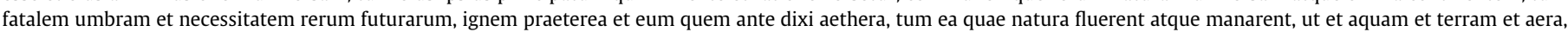

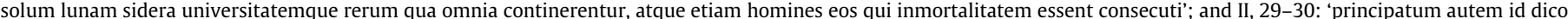

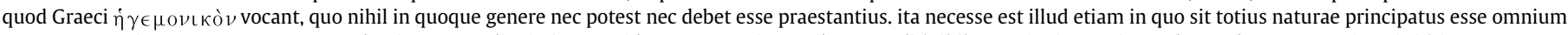

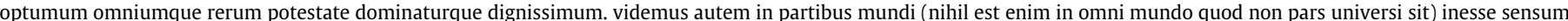

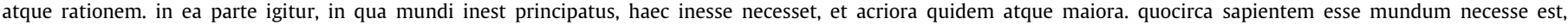
naturamque eam quae res omnes conplexa teneat perfectione rationis excellere, eoque deum esse mundum omnemque vim mundi natura divina contineri'.

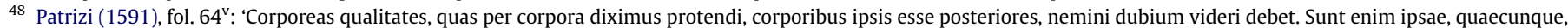

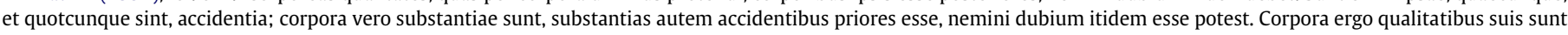
priora'.

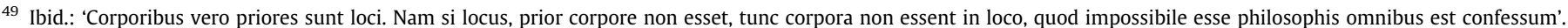

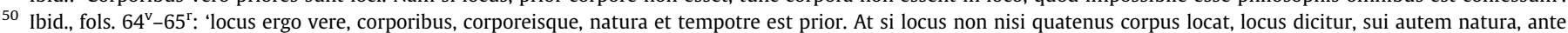

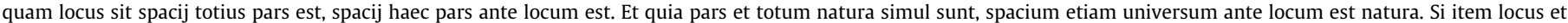

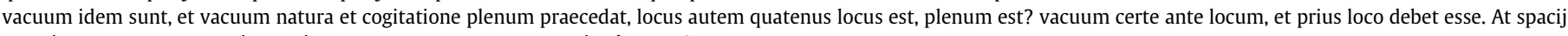
proprium est, ut vacuum sit, spacium ergo natura, et tempore prius loco est'.

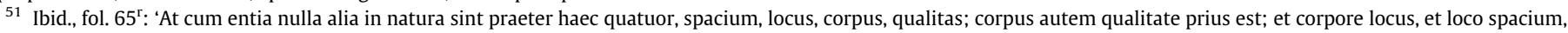

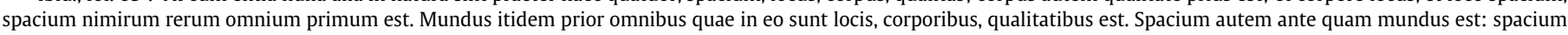
nimirum, mundanorum omnium primum erit'

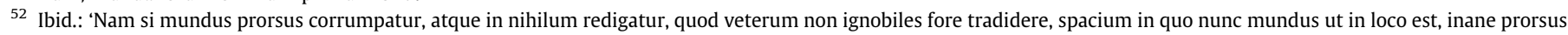

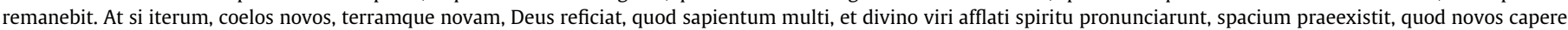
possit coelos, terramque novam'.

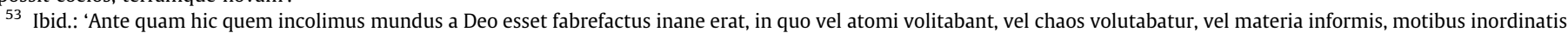

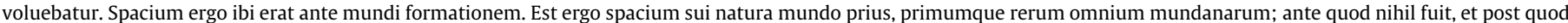

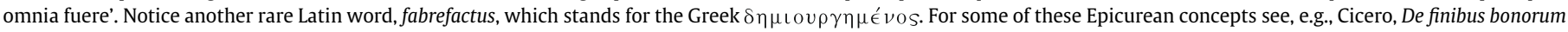

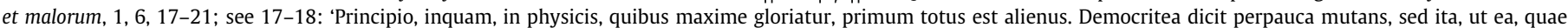

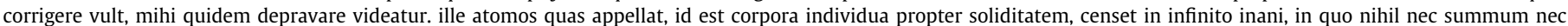

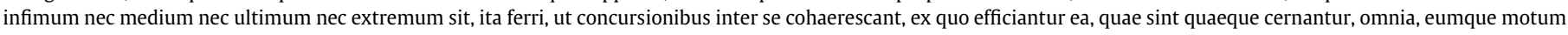

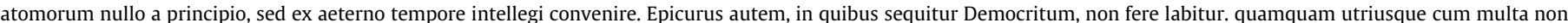

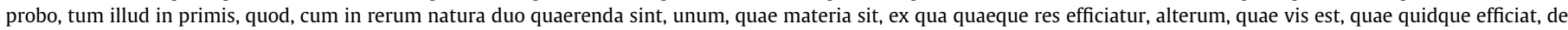
materia disseruerunt, vim et causam efficiendi reliquerunt'.
} 
First, Patrizi states, space seems to be nothing more than an aptitude for holding or sustaining all the bodies. ${ }^{54}$ But if it would be part of the physical reality of the world it should be either a substance or an accidental thing. And if it is a substance it should be either incorporeal or else a body. If it is accidental then it should be either quantity, or quality, or anything else of this kind. ${ }^{55}$ Patrizi is playing here with the Aristotelian distinctions that all of his readers are familiar with. But then he continues:

We say indeed that space in itself, since it precedes the world and is beyond the world, is none of the worldly matters except of that part of it which holds the world, or that the world occupies [that part] with its body. But in truth [space] is a different thing from the world [and] a diverse one. ${ }^{56}$

So, Patrizi is directly rejecting here the Aristotelian categories and he regards them as totally irrelevant for the discussion of space: space is superior to the world and to everything which is included in it (and which is subjected to the Aristotelian categories) in any possible way. What then is space and what is the difference between space and world, if we remember Patrizi's earlier statement, that space is body?

Indeed the world is a body, but space is in no way a [natural] body, therefore none of the categories embraces space: it exists before and beyond all these [categories]. Therefore what is it? It is a hypostasis, a distance, a separation; it is an extension, a stretching out, an interval, it is an interruption and a pause. Therefore quantity? Therefore accident? Therefore accident before substance? And before body ${ }^{57}$

Aristotelian categories simply do not work when we discuss the notion of space. Patrizi does not contradict himself while claiming here that space is not a body, since he means that it is not a sublunar worldly body in the Aristotelian sense. Previously (n. 16 and context) we had a similar, but not identical, set of terms: dimensio, distantia, intervallum, intercapedo, spacium, diastasis, diastema. It is important to notice how Patrizi tacitly brings in here the terms hypostasis, ectasis, and extensio, thus preparing the ground for his next dialectical move in determining what space is. What we have here can be regarded as terminological rhetoric: Patrizi is placing in front of his readers a whole set of terms, some of which are not very common in Latin, ${ }^{58}$ and contrasts them with the Aristotelian categories. In this way he is in fact trying to create a new scientific discourse, not Aristotelian in nature, and quite original, in which the notion of space is at the centre.
And what about authorities? At least some of the readers will be expecting some alternative names to go along with the alternative terminology. The only name mentioned in this context is Archytas (early fourth century BC), a Pythagorean from Tarentum who was a friend of Plato, and some followers of Aristotle, but Patrizi stresses the fact that, since they did not know about this notion of space, they still followed the Aristotelian categories. ${ }^{59}$ Now the ground is ready for another attack on Aristotle's categories, through which Patrizi will present two more answers to the question what space is, beyond aptitude.

Emphasizing the fact that the Aristotelian categories are clearly posited in worldly matters, and thus essentially connected to the world and its contents (bodies and qualities), while space is essentially different from all these worldly matters, and thus ontologically and epistemologically separated from the world, Patrizi concludes that space stands before and beyond the Aristotelian notions of body, non-body, substance, and accident, notions upon which the categories are based; in fact, all these notions should be regarded only as accidental with regard to space. In other words, Patrizi is presenting here another distinction, between one substance which is space, and many accidents, which include everything which is not space. This requires a different way of philosophizing regarding space, without using the categories. ${ }^{60}$ And here Patrizi offers his second answer:

Therefore, space is a hypostatic extension which stands on its own [and] adheres to nothing. It is not quantity. And if it is quantity, it is not that of the categories, but rather [a quantity which stands] before that of the categories, and it is its source and origin. ${ }^{61}$

It is now clear why Patrizi added to the list of terms we have just seen hypostasis and extensio; he already thought of his second answer: space as extensio hypostatica. This phrase is another example of Patrizi's originality, this time obviously inspired by the Neo-

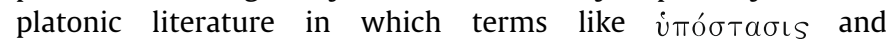
ímoбTaтıkós are most common. Extensio may have reminded some readers of the Aristotelian category of quantity, and Patrizi immediately rejects this possibility. What about the Aristotelian substance? In order to avoid any identification of extensio hypostatica with an Aristotelian quantitas substantiva or substantia

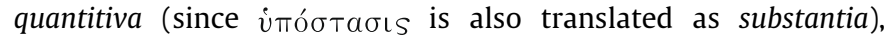
Patrizi sharply distinguishes between space as substance, and the substance of the Aristotelian categories, using powerful rhetoric, in which he repeats the formulation 'if substance is $\mathrm{X}$ then space

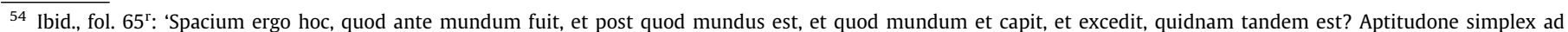

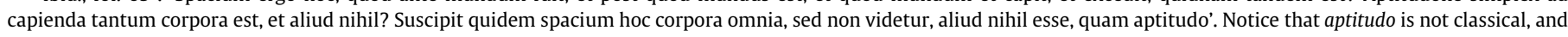

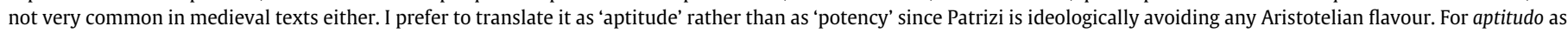
'potency' see Deitz (1999), p. 150.

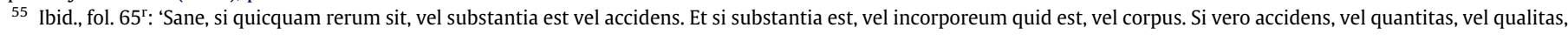
vel aliud tale'.

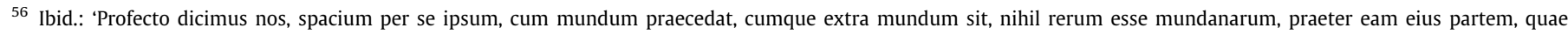
mundum capit, aut quod mundus suo corpore occupat. Verum alia res a mundo diversa est'.

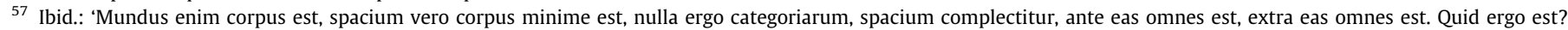

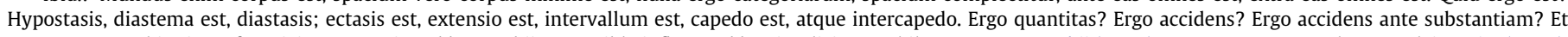

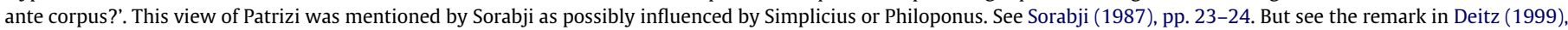
p. 165 n. 58.

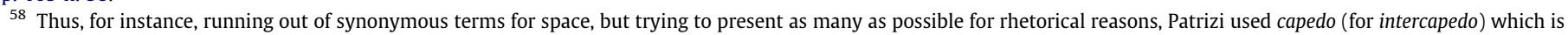

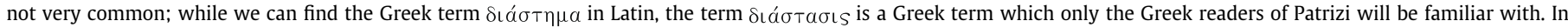
general, these terms are quite technical, and some of them are not classical, facts which again will make it harder for the readers to follow Patrizi's arguments.

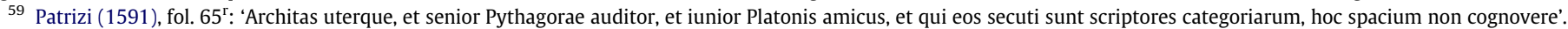

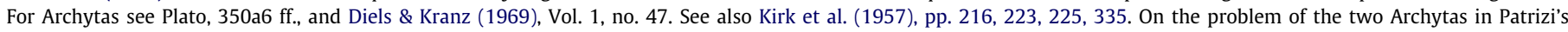
Discussiones peripateticae, see Deitz (2007), pp. 117-121.

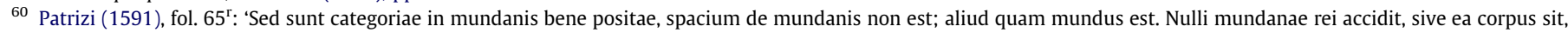

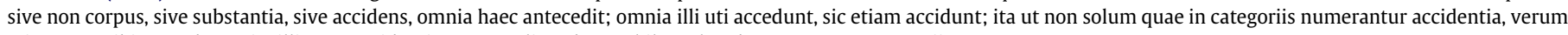
etiam quae ibi est substantia, illi sunt accidentia. Itaque aliter de eo philosophandum, quam ex categoriis'.

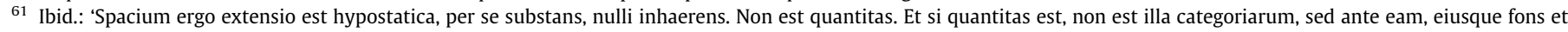
origo'.
} 
is the most substance among all things'; this rhetorical repetition represents once again Patrizi's effort to create a new scientific terminology in which spacium as extensio hypostatica should replace the Aristotelian notion of substantia. And thus, space as a substance stands by itself, it is the most substance in comparison to all other things, it does not lean upon anything for its existence. It offers substantiality to substances and supports them so that they would exist, and it is present in all other things in nature. Space as substance conducts everything else and causes its existence while not being conducted by anything, and if substance is the first among all beings, then space is the most substance among all beings. ${ }^{62}$ Patrizi still wants to be sure that his readers would not confuse space and Aristotelian substance before presenting his third answer to the question what space is:

Therefore, from all these arguments it is most evident that space is the most substance among all things, but it is not that substance of the categories, since it is not an individual substance, since it is not composed of matter and form. And it is not a genus, since it is not predicated either of species or of particulars, but rather, it is some other substance which is beyond the one of the categories. ${ }^{63}$

While determining whether this special substance is corporeal or incorporeal, Patrizi reaches his third definition of space, again presenting the same conceptual flexibility:

Would [this substance] then be a body or is it an incorporeal substance? [It is] neither, but rather [this substance would be] in the midst of these two possibilities. It is not a body, since it is not resisting, nor is it opposing or struggling against [other bodies]; it is not exposed or subjected to either sight or touch, nor to any of the senses. And again, it is not incorporeal, since it includes three dimensions, length, breadth, and depth, not one, not two, or more [i.e. than three], but rather all [three]. And thus it is an incorporeal body, and a corporeal non-body. ${ }^{64}$

Patrizi is here rejecting the distinction between corporeal and incorporeal substances. Space stands beyond this distinction. The third definition of space we have here is again inspired by Neoplatonic dialectic and rhetoric. ${ }^{65}$

Moving on to discuss the qualities of space (both empty space and place-space), Patrizi contends that space, while being the source of movement for anything that moves, is essentially immovable and empty. ${ }^{66}$ In determining the relations between the two parts of space, Patrizi argues that space cannot be considered as a whole since it has two different parts: one is full of the world and the other is empty and it is outside the world; one is finite, and the other, as we have seen, is both finite and infinite. ${ }^{67}$ But what about the powers of each part? It seems reasonable that the part which is both finite and infinite should have greater powers, since infinity is superior to finitude. ${ }^{68}$ It is also reasonable that in that part of space which acts upon another part, which is passive and receiving this activity, there are greater powers. ${ }^{69}$ This creates an unequal state between different parts of space, and the question then will be from where does this unequal state of powers comes from. ${ }^{70}$ While dealing with the question from where space received these powers, either from the chaotic state before the formation of the world, from unformed matter or from the atoms, or rather from the world after it was formed, Patrizi is focusing on the nature of the act of receiving (receptio), and whether it is an activity or a receptivity. Showing again his conceptual flexibility, Patrizi explains how receptio is at once both activity (actio) and receptivity (passio) and yet neither of these two. ${ }^{71}$ Receptio is thus the first power of space, but is it the only one? Apparently not. Patrizi immediately adds to it an internal power of placing (locandi) and an external power of surrounding

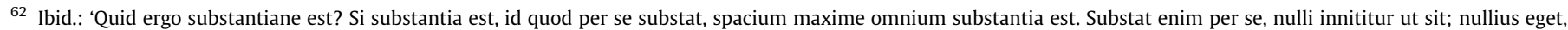

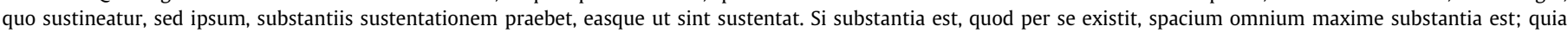

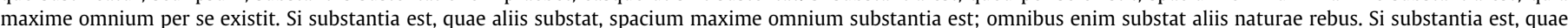

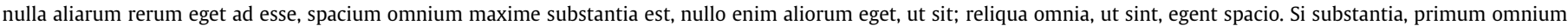
entium est, spacium maxime omnium substantia est. Primum enim aliarum rerum omnium esse iam est probatum'.

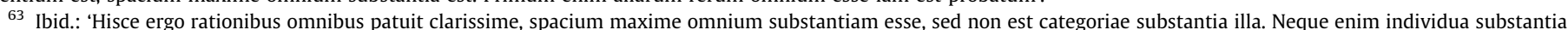

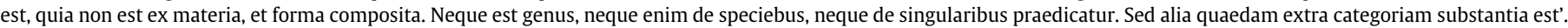

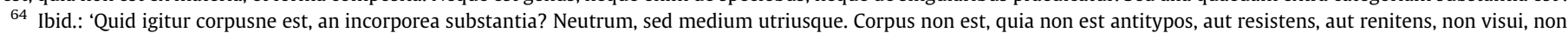

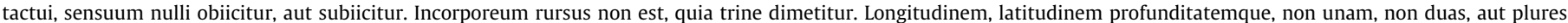

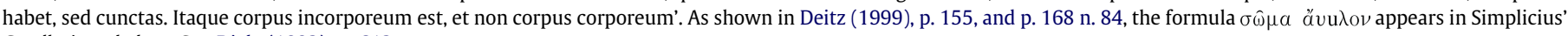
Corollarium de loco. See Diels (1882), p. 612.

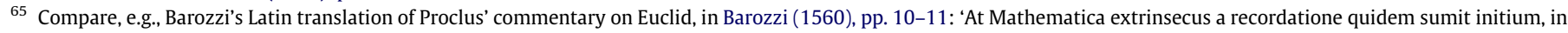

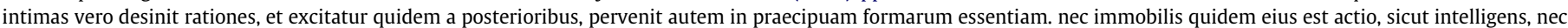

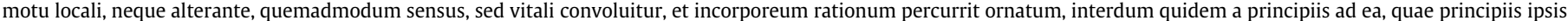

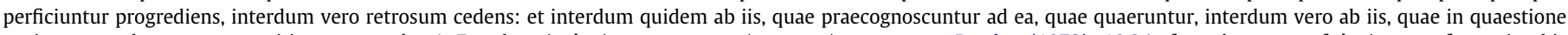

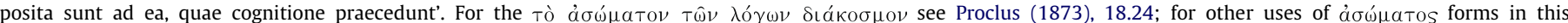

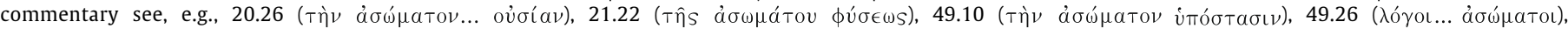

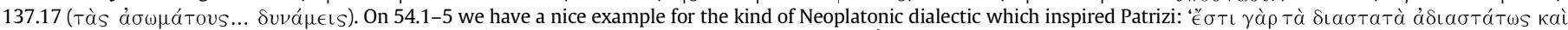

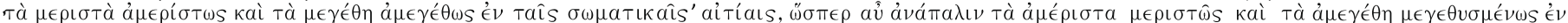
Taîs $\sigma \omega \mu$ atıkấs

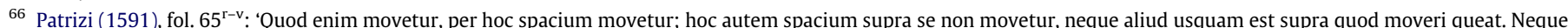

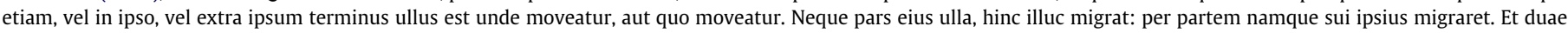

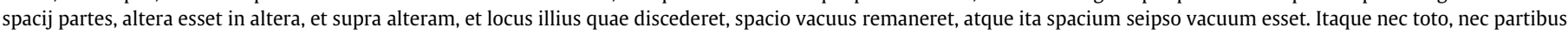
movetur. Est ergo et immotum prorsus, et omnino immobile'.

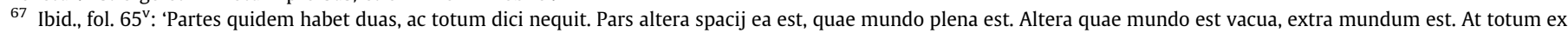

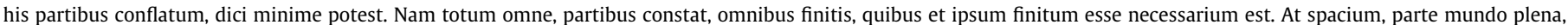
mundo finibus finitum, et equale est. Parte autem mundo vacua, extra mundum posita, finitum infinitumque, uti docuimus, est simul'.

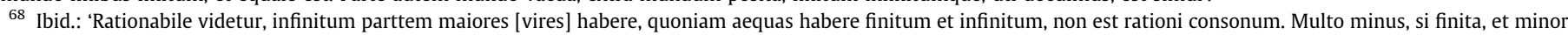
pars, maiores habere dicatur'.

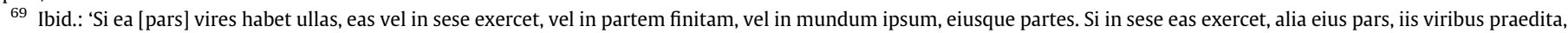

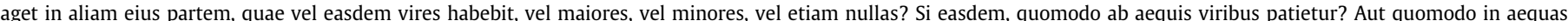

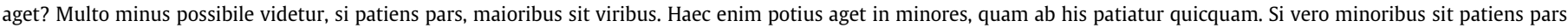
praedita, poterit a maioribus forsitan pati aliquid'.

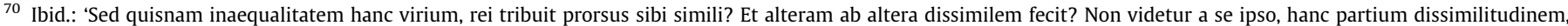
spacium illud acquisivisse. Ergo ab alio'.

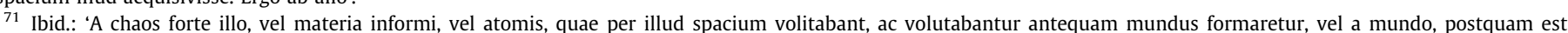

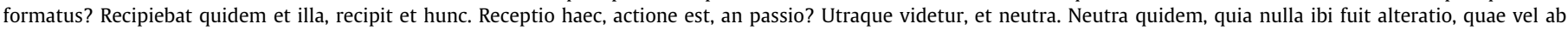

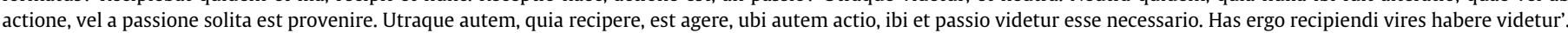


(ambiendi). These two powers act upon the world and thus they belong to the infinite part of the empty space. ${ }^{72}$ And what about the powers of the finite space in the world? It also has these three powers of receiving, placing, and surrounding, but it has other three: the power of penetrating (penetrandi) into all bodies; the power of uniting (uniendi) itself with the particular spaces of bodies; and the power of providing (dandi) these powers with a place in the movements of bodies. ${ }^{73}$ And here we finally have one authority mentioned: Hermes, the wisest among the Egyptians, who claimed that the movement in the world can be caused only by something immovable, and the only things immovable in the world are space and earth. ${ }^{74}$ Obviously, this reference relates Patrizi to the Florentine humanism of the last decades of the fifteenth century and especially to Marsilio Ficino, for whom the figure of Hermes Trismegistus became part of the ancient theologians (prisci theologi) and the ancient theology (prisca theologia). ${ }^{75}$

Patrizi is describing a new physics in which everything in the world is moving due to space: the animals above and below the earth, but also the principal bodies of the world, which hold the power of movement due to the fact that they are placed in a place and they are not separated from it. The centre of the world would be always at the centre of space, and the earth is in the same space around the centre and it always remains unmoved. Also water, air, and the whole heaven belong to space. ${ }^{76}$ Thus, the bodies of the world, the heaven and the elements, occupy from the beginning their proper parts of space, where they are placed, and they would always maintain these parts. ${ }^{77}$ Just as all the worldly bodies differ from one another by nature, so the parts of space which are subjected to the particularity of these bodies seem to differ from one another; but this difference among parts of space, Patrizi contends, since its origin are these placed bodies, should be regarded only as accidental, unless it will be proved that these parts of space were thus disposed from the beginning, so that this part would hold for instance the earth but not the air, and another part would hold water, but it would not be able to hold the heaven, the air, or the earth. But in fact, any part of space held its peculiar bodies, so if this is the case, Patrizi argues, this peculiarity is necessarily placed into each one of these bodies by another superior power. And the question as to whose power this power is, and what is its nature, of any body, and that superior power, will be discussed later, in its place. ${ }^{78}$

Patrizi's notion of physical space goes beyond the Aristotelian physics and its most basic concepts. Instead of the categories, substances and accidents, we have a notion of space which is a hypostatic extension, a minimal body, the first and only real substance which is totally dependent upon itself, but all other beings are dependent on it for their existence. Space exists before and beyond the world, only due to space does the world exist and could be created again in case of a Stoic conflagration. This new notion is presented by Patrizi by way of a dialectical definition, using conceptual flexibility, through which all the Aristotelian assumptions are left behind. Thus, for instance, vacuum characterizes space and exists before fullness, and so, empty space comes before the world which is full of bodies and qualities in Patrizi's hierarchy of entities. Patrizi explains how space can be at once finite and infinite, a body without resistance which is not subjected to any of the senses but still has three dimensions, and thus, it cannot be determined according to the dichotomy corporeal/incorporeal. Let us move now to discuss Patrizi's notion of the mathematical space.

Patrizi's starting point is to note the implications of the fact that space is both really $(a c t u)$ finite and infinite. Being infinite, space has no powers to become greater than itself, or to enlarge itself in any part, since it is equally diffused in all parts. Space is in fact (simpliciter) the biggest among all things. ${ }^{79}$ But that part of space which is finite is, on the other hand, the smallest thing in reality or in the world (in rebus). ${ }^{80}$ Patrizi immediately connects magnitude or quantity and divisibility:

And just as the biggest thing can be mostly divided, so the smallest thing can only minimally be divided. And this should be understood of each of the two parts of space; and just as that infinite space is infinitely divisible, so the finite space is finitely divisible. ${ }^{81}$

This connection enables Patrizi to reject 'an ancient dogma' according to which any quantity can be infinitely divided, and to accept a contrary view. ${ }^{82}$ It is in this context that Patrizi introduces his definition of a point:

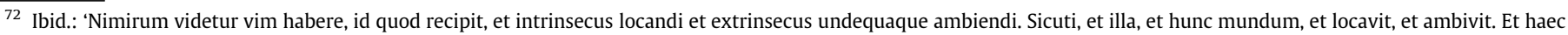
quidem de infinito illo'.

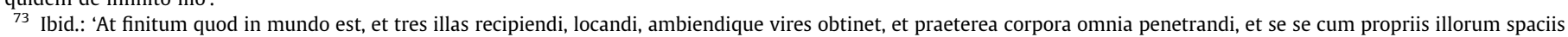
uniendi. Et ad has corporum motibus locum dandi'.

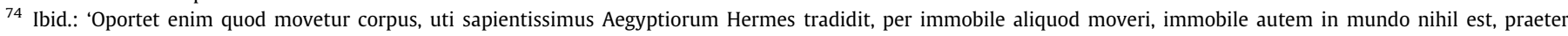

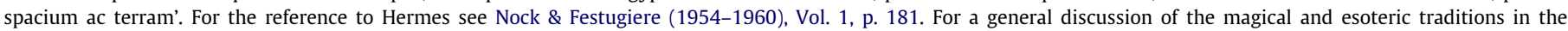
Renaissance see Vasoli (2002), pp. 133-153, and see the classical study by Yates (1964).

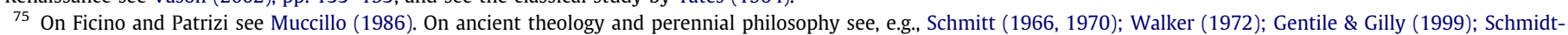
Biggemann (2004).

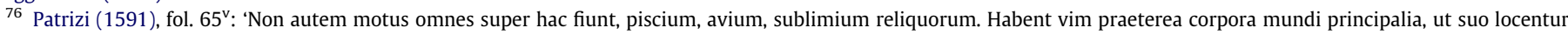

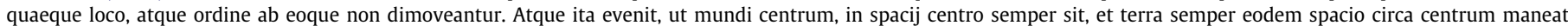
immobilis; et aqua suo, et aer, et coelum universum'.

77 Ibid.: 'Quod si sic est, mundi corpora, coelum nempe et elementa, partes spacij sibi proprias a principio occuparunt, quibus locarentur, ac perpetuo obtinerent'.

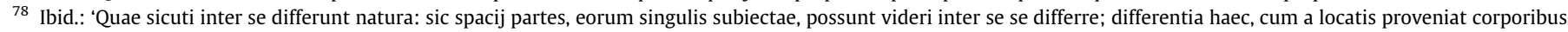

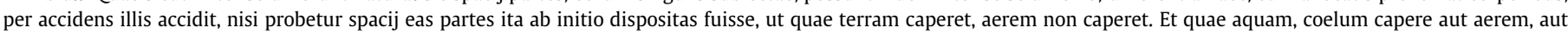

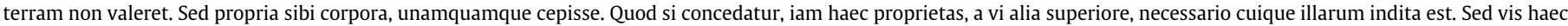
cuius fuerit, et quae, suo loco perquiretur'.

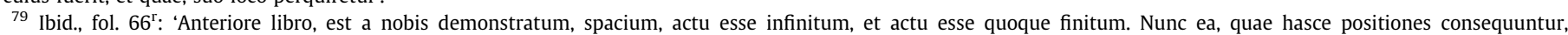

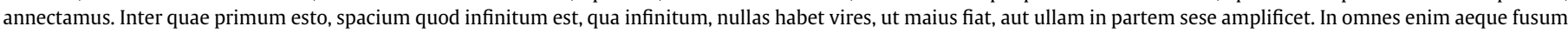

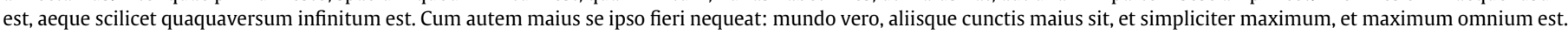

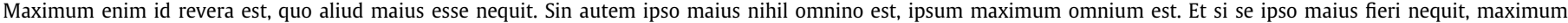
simpliciter est'.

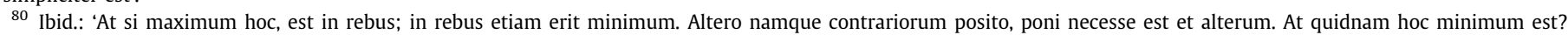

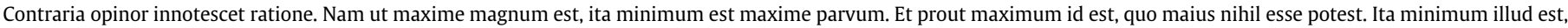
quo minus esse nequit. Et sicut maximum est infinitum, sic minimum erit finitum'.

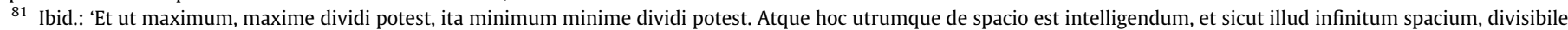
est in infinitum, sic finitum, divisibile est in finitum'.

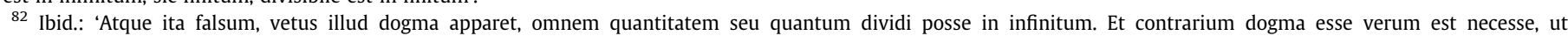

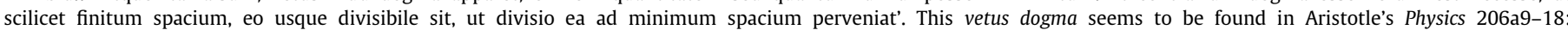

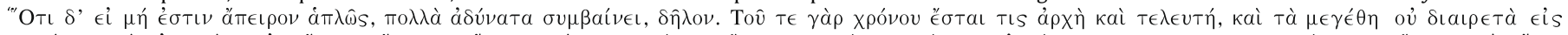

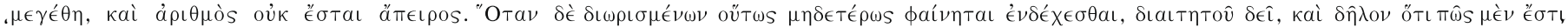

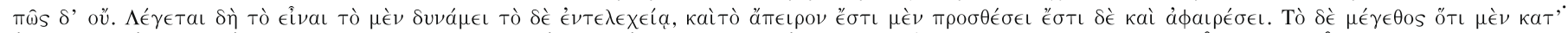

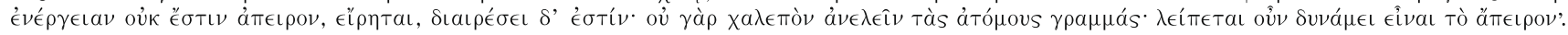


But there would be some smallest thing in space which differs from space, that is, [it is] not space. And this thing is what the ancient geometricians called a point, and we, too, shall call it a point. ${ }^{83}$

A point is not a space and it has no dimension; on the other hand, Patrizi determines that space, being contrary to point, contains all dimensions. For this reason space contains all parts while point is completely without parts, and so, it is indivisible. ${ }^{84}$ What we have here is in fact the first two components of the mathematical space which are its two contrasted poles: space (which is like a container) on the one hand, and point (which is inside this container) on the other. Between these two we shall find all the other members of the mathematical space. Just as we have seen in the case of the physical space, Patrizi will now determine the relations and hierarchy between these members. If point is indivisible, we should first distinguish it from other indivisible concepts like unity (unitas), a moment of time (momentum temporis), and a moment of movement (momentum motus). Starting with the last two Patrizi contends that they are posterior to point: time comes either after, or together with, movement. ${ }^{85}$ Time and movement are the two most remote (or else last) concepts in the mathematical space with regard to point, which, as we shall shortly see, is the first one. Time is posterior to movement, and movement comes before bodies. And before bodies we have yet three more stages: three dimensions, two dimensions, and one dimension. First dimension is just after point, which comes before everything else in the mathematical space. ${ }^{86}$ Coming back to the concept of unity, Patrizi claims that it is essentially identical to point, only that both concepts are related to different things: while point is related to line, unity is related to number. ${ }^{87}$ We can see here how Patrizi adds more and more members to the mathematical space, thus creating, on an epistemological level, a mathematical discourse, so far containing time, movement, bodies, three dimensions, two dimensions, one dimension, and before everything else a point, which is identical to unity (which is related to number), but is related to line.

While clarifying the relation between point and line Patrizi criticizes the Aristotelian idea according to which point is the beginning or origin (principium) of line (just as unity is the beginning or origin of number), since such relation brings the notion of production or creation into the picture (suggesting that line is produced or created by point), and this production involves movement, which as we have seen, is only in the fifth stage (after bodies, three dimensions, two dimensions, one dimension, and point). So we cannot, according to Patrizi, relate movement directly to point. And thus we should determine again the relation between point and line, leaving out of this explanation concepts like principium, productio, and motus. ${ }^{88}$ At this point Patrizi introduces his definition of line:

\section{- What then is a line? [It is] that part of space which lies between two points. ${ }^{89}$}

This definition brings the notion of number back, since two points were mentioned. This means that there are in fact (actu) two points in space, and thus, also a number or quantity. ${ }^{90}$ This raises the question of which concept comes first, number or line, a question that, according to Patrizi, should not vex later thinkers the way it tormented the ancient ones. His answer is that none of these concepts comes before the other, they come at the same time and depend one upon the other. ${ }^{91}$ Patrizi agrees with the Pythagoreans that number one consists of two and corresponds with line; two consists of three and corresponds with a surface; three consists of four and corresponds with a body. ${ }^{92}$ And so, the part of space between two points is a line, between three is a triangular surface, between four is the first body, a pyramid, and then more points just create other three dimensional bodies. ${ }^{93}$

Once again we find in Patrizi a perfect correspondence between the structure or grades of reality and the science through which we can understand this structure. We are thus led through the grades of reality in nature, going from points, lines, surfaces, bodies, unity, and numbers. Mathematics is the science connected to these concepts, which being in that infinite space, are also infinite. ${ }^{94}$ Criticizing ancient thinkers for not understanding the relation between these concepts and infinitude, Patrizi mentions four arguments by the ancients concerning point, line, and number, and their infinite magnitude, division, extention, and increment, and he then gives his own account regarding these arguments, emphasizing his strong

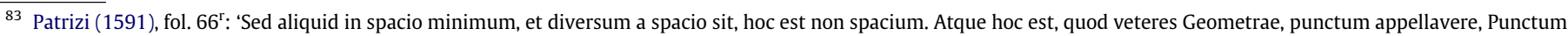
et nos appellemus'.

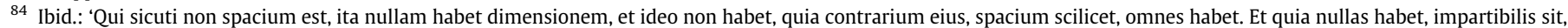
et indivisibilis'.

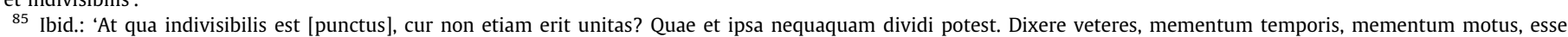
indivisibilia. Sunt, sed puncto sunt posteriora. Tempus enim post motum, vel cum motu est'.

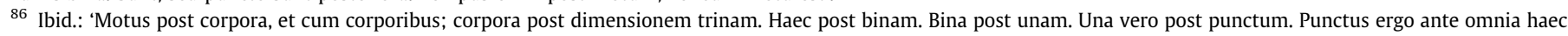
est, quia in spacio, omnium primus, positus est'.

87 Ibid.: 'Qui itidem unitas est. Verum cum essentialiter ambo idem sint; nomina, ad aliud relata, sunt sortita. Punctus relatione ad lineam, unitas relatione ad numerum'.

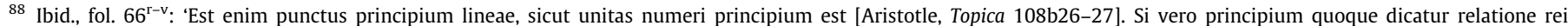

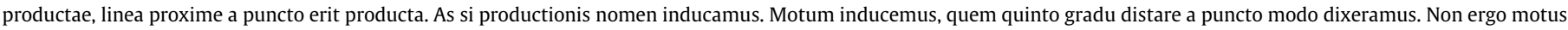

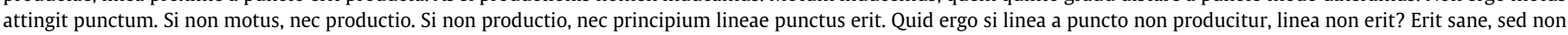
producta. Nec erit linea punctus fluens quod veteres aliqui autumarunt'. On principium see also nn. 46 and 47 above and context.

89 Ibid., fol. 66 $6^{\mathrm{v}}$ : 'Quid ergo linea est? Pars ea spacij quae inter duo puncta interiacet'.

90 Ibid.: 'Cum autem duo puncta dico, iam et numerum induco. Et sunt in spacio duo puncta actu. Itaque numerus actu una cum continuo est'.

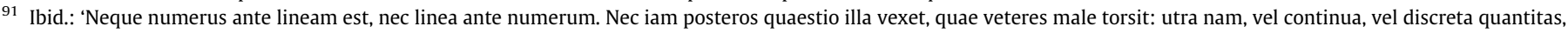
natura antiquior esset, ac prior. Simul enim sunt. Neque est altera ante alteram, nec altera sine altera est, nec esse potest'.

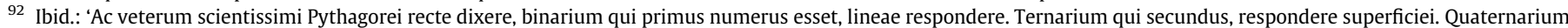

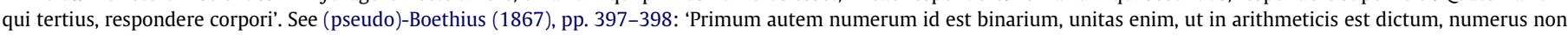

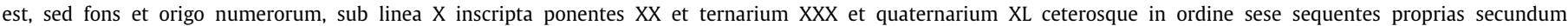
denominationes assignare constituerunt'. These ideas are ascribed to the Pythagoreans on p. 396.

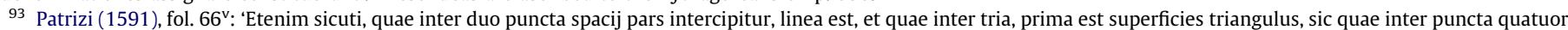

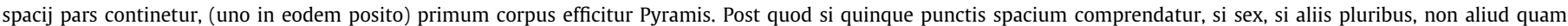
corpus absolvent. Hoc est trinam dimensionem, longum, latum, et profundum'.

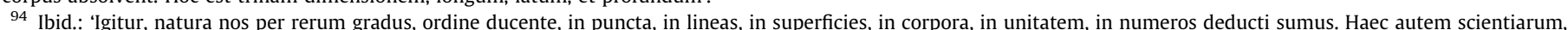

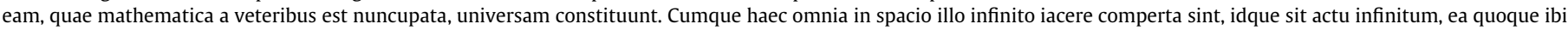
infinita, et actu infinita esse, est necesse'.
} 
objection to the second one, according to which it is possible to divide a line which is between two points infinitely. ${ }^{95}$

After presenting his detailed objection via different arguments and paradoxes concerning infinite division of any line and quantity, stressing the precedence of continuity and indivisibility to discontinuity and division, and the fact that a line is a quantity which is not composed of points, but rather simple and without any parts, ${ }^{96}$ Patrizi concludes that the first space is indivisible either by any force of nature or of the human mind. But, according to its very nature, divided body has been placed in its continuous parts. ${ }^{97}$ But, our philosopher contends, at any time it wishes, a thing can be regarded or considered by the mind as divided. Thus, lines, surfaces, bodies, and incorporeal things are all in fact ( $a c t u$ ) infinite in number and magnitude, that is in their lengths, breadths, and depths, they are just immeasurable and endless in reality (re ipsa). But all these things are imagined by us as finite. Our mind, out of its own necessity, assumes that those things which can be accommodated to the spaces of the worldly bodies are finite. ${ }^{98}$ And here we find Patrizi's account of the mathematical process and his epistemological theory, as opposed to Aristotle's famous view of the mathematical process as abstraction. ${ }^{99}$ The reason for rejecting this Aristotelian theory is that those spaces are not in themselves part of the worldly bodies, but rather they really exist before bodies in the first space. ${ }^{100}$ These dimensions are not created by our imagination or by our discursive thinking. They have subsistence. ${ }^{101}$ And so

But the mind cuts off by its own force from that first space these parts which are going to be of use to it either in thought or in action. ${ }^{102}$

Patrizi emphasizes that, although some of these parts of space are continuous and some are divided, the last were in fact cut off from the first. ${ }^{103}$ He then gives his account of the act of the mind, continuous space, division, and point:

And the continuous [space] is always in actuality; indeed it is not divided by the mind neither in actuality nor in potentiality, but it is only imagined as divided. And just as the first continuum is in reality the largest, so in it, also in actuality, since it is necessary that the smallest [entity] exists, it would be necessary that each of these two contraries exist in nature and in things. And just as the biggest continuous [space] is a thing, of which nothing can be bigger, so the smallest continuous [space] will be that thing of which nothing can be smaller. And just as the biggest magnitude is that of which nothing can be bigger, and it is the whole and total which can exist, so also the smallest magnitude will be that of which nothing can be smaller. And that is total in its smallness as much as possible. And still this thing is not [as small as the] point which we described above as the smallest [entity] in space. But we said that [point is] the smallest magnitude, the smallest space, or the smallest [member] of space. In this [account], that division of the continuous [space] which was considered infinite, should necessarily stop. ${ }^{104}$

The concept of mathematical space is beyond the comprehension of our mind, and its division (either finite or infinite) is completely imagined by the mind. This first space or any of its members cannot be grasped by sense perception, claims Patrizi. ${ }^{105}$

It is clear, then, that this continuous space, by its very nature, is more ancient and previous to any division, done by the power of human cognition which produced number. ${ }^{106}$ This leads Patrizi to his account of number, in which he accepts the ancient Aristotelian view of number as divided quantity (discreta quantitas), but criticizes ancient thinkers for guessing more than understanding this issue. According to our philosopher there is continuous quantity in nature, while number is the creation of the human mind, and so, continuity is totally superior and previous to division, which is dependent upon the existence of continuity which can then be divided. ${ }^{107}$ Solving what is presented as a difficult question for both ancient and contemporary thinkers, Patrizi contends that the knowledge or science of continuous things, which originated from the measurements of territories or lands (ab agrorum dimensionibus) and not from the nature of a thing (ex rei natura), and is thus called geometry (geo-metry), comes before the knowledge or science of divided things, which is called arithmetic. ${ }^{108}$ Arithmetic, he says, has now been shown to have originated in geometry and to be inferior to it. Relating once again ontology to epistemology Patrizi argues that since

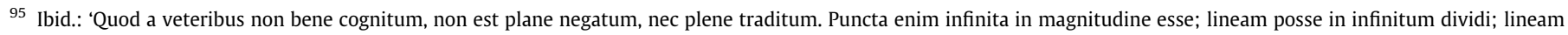

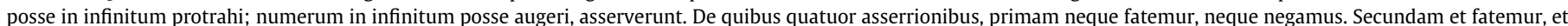

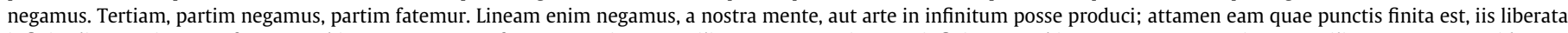

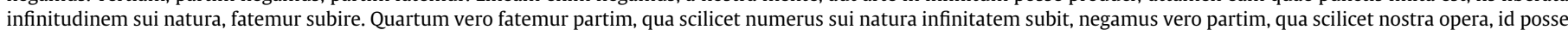

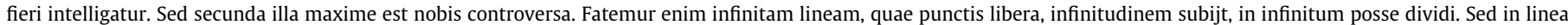
punctis terminata ac finita (sicuti veteres acceperunt, et docuerunt) id vero maxime pernegamus'.

96 Ibid., fols. $66^{\mathrm{v}}-68^{\mathrm{r}}$

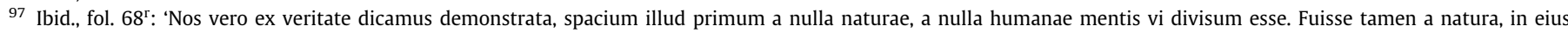
partibus continuis, divisa corpora collocata'.

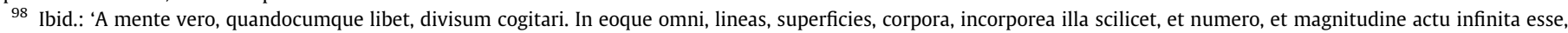

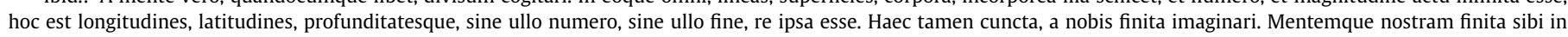
opus sumere, quae spaciis mundanorum corpororum possint accommodari'.

${ }^{99}$ Ibid.: 'A quibus corporibus non per abstractionem, mens ea separat, ut quidam contenderunt'. See Aristotle, Analytica posteriora 81a38-b9; De anima 431b12-19.

100 Patrizi (1591), fol. 68 r: 'Quoniam ea spacia non sunt primo, et per se in mundanis corporibus. Sed sunt ante corpora, actu in primo spacio'.

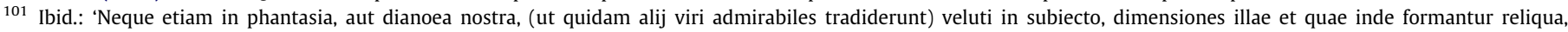
subsistentiam habent'.

102 Ibid.: 'Sed mens e spacio illo primo vi sua, eas partes desecat, quae sibi sunt, vel contemplationi, vel operi, usui futura'.

103 Ibid.: 'Easque omnes, vel continuas, vel discretas. Continuum autem asserimus esse, id quod extenditur. Discretum vero, quod de continuo desecatur'.

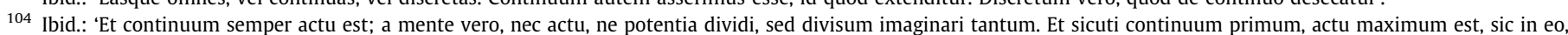

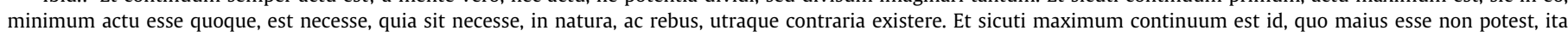

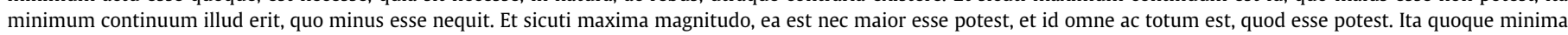

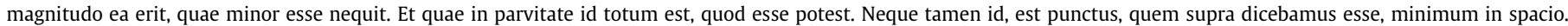
Minimam autem magnitudinem dicimus esse, minimum spacium, sive spacij minimum. In quo sistetur necessario illa continui divisio credita in infinitum'.

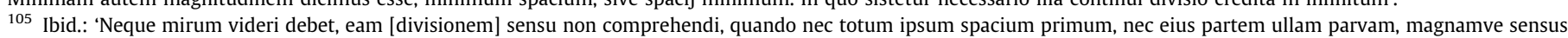
percipit'.

106 Ibid.: 'Patuit quoque, continuum sui natura, omni divisione antiquius ac prius esse; cuius divisio, ac desectio, humane cogitationis vi facta, numerum procreasse'.

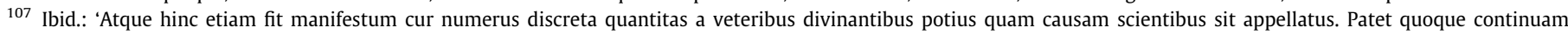

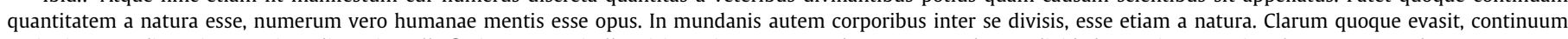
antiquius esse discretio. Quoniam discretio nulla fieri posset a vi ulla, nisi continuum antecederet'. For number as divided quantity see Aristotle, Categoriae, 4 b22-23.

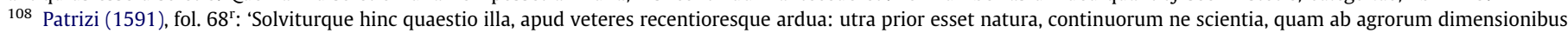
non ex rei natura, Geometriam appellavere; an discretorum, quam Arithmeticam dixere. Hanc scilicet diximus ex illa nasci, atque ideo secundam esse'.
} 
space is the first among all things in nature, both its sciences, geometry (the science of the continuous) and arithmetic (the science of the divided) exist before matter. ${ }^{109}$ And what about the status of mathematics in a more general perspective?

And mathematics is in the middle, between the entirely incorporeal and the entirely corporeal, not because of the reason given by the ancients, according to which [mathematics] through abstraction from natural things almost becomes corporeal, but rather since in fact space is body incorporeal and incorporeal body. Thus it happens that through its body [space] holds relationship with things and bodies in nature, in what concerns their dimensions. But to its incorporeal aspect, inasmuch as it is truly and plainly incorporeal. And it would be closer to that [incorporeal aspect] than to any body in nature. By this same progression of arguments it would be clear to some one who is engaged in the contemplation of things in nature that the science of space should both be regarded and transmitted as superior to either natural [science] or to that [science] which deals with actions and passions of human beings. For also these [actions and passions] are posterior to operations in nature, and these same operations are in the same way posterior to space. ${ }^{110}$

Mathematics is thus superior to both ethics and natural science, since its object, space, is superior to nature and to human concerns. Patrizi is criticizing here Aristotle's notion of the mathematical process, and mathematics as $\mu \in \tau \alpha \xi \dot{v}$, as it appears for instance in Metaphysics 1059b6-16. Aristotle put mathematics between $\tau \grave{\alpha} \epsilon \iota \delta \eta$ and $\tau \grave{\alpha}$ ai $\sigma \theta \eta \tau a ́$ and thus left it in a rather inferior status. We can find a similar emphasis on mathematics being in the middle, but between indivisible and simple substances, and divisible ones, that is, in essentially higher status than that we have found in Aristotle, in the opening lines of Proclus' first prologue to his commentary on Euclid. Let us examine Barozzi's translation of this opening section:

It is necessary that the essence of mathematics would neither be located among the first, that is the genera, nor among the last, that is those things which are separated from simple essence, but rather it occupies a place in the middle, between indivisible, simple, and not compounded substances on the one hand, and divisible substances which are bounded by parts, and by manyfold compositions and different divisions, on the other. Indeed, with regard to the reasonings which are taught in [mathematics] itself, [mathematics] holds itself always in the same way, and [this way] is firm and cannot be refuted; it shows that it, in itself is superior to forms which are held in matter. But this faculty of advancing which comprehends, and besides it both uses the dimensions of things subjected to it, and derives different things from different principles, offers itself an inferior rank; according to this rank which [mathematics] obtains it is indivisible, and is perfectly arranged in itself by nature. ${ }^{111}$

- But mathematics, and all things, in general, which are subjected to thinking, have been allotted a middle place. They are superior to those things which are conceived by division, and take precedence over sense objects, since they are free of matter. They are superior to the first (divisible things) in a simple manner, and take precedence over the second (sense objects) for a sure reason. And they have more open notions of intelligent being than sense objects, but are still only reflections of it. And in a divisible fashion they imitate exemplars which are indivisible, and in a multiform manner exemplars which are uniform. To cut it short, they are placed in the vestibule of the prime forms, and open before them an existence which is unified and indivisible and fertile, although they themselves cannot overcome division, and composite reasons, and a substance which is appropriate for images; nor can they bypass the different mental notions which have the force of thought, and join the simple cognitions which are free of all matter. The middle position between taken by the genera and forms of mathematics can be understood in this description. They occupy a middle position between plainly indivisible essences and those which, related to matter, are divisible. ${ }^{112}$

We find in these two passages from Proclus expressions like partibiliter quidem impartibilia, multiformiter autem uniformia exem-

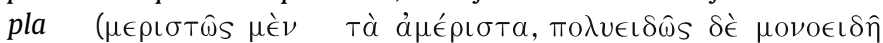
$\pi \alpha \rho \alpha \delta \in \epsilon^{\prime} \gamma \mu \alpha \tau \alpha$ ), which resemble (from the rhetorical-dialectical aspect common to Neoplatonic literature) Patrizi's formula corpus incorporeum et incorporeum corpus. There is no doubt that the

\footnotetext{
109 Ibid.: 'Cumque spacium sit rerum naturae omnium primum, eius Scientiam utramque, et continui et discreti, ante materiam esse, est manifestum'.

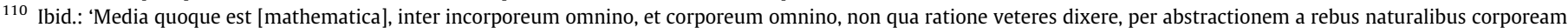

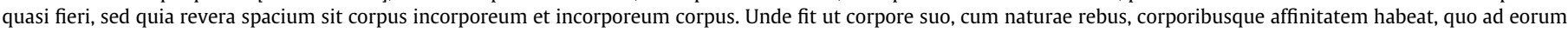

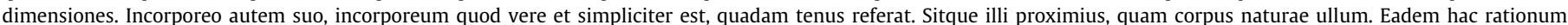

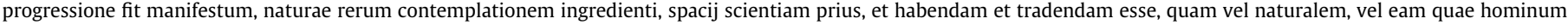
actiones, passionesque compraehendit. Nam et hae, naturae operibus posteriores sunt; et haec ipsa opera spacio itidem sunt posteriora'.

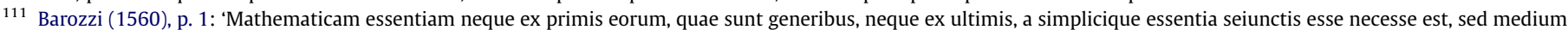

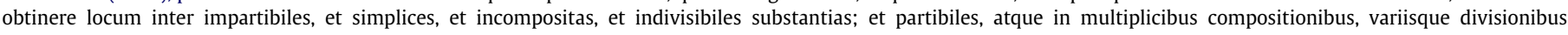

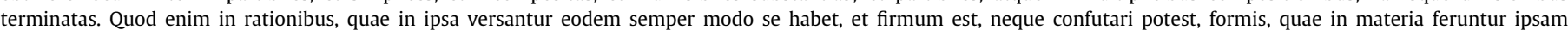

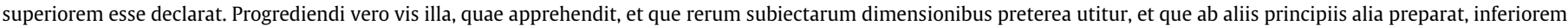

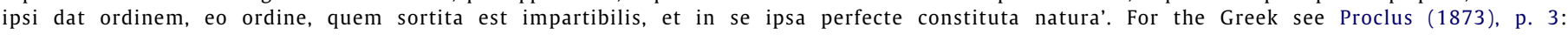

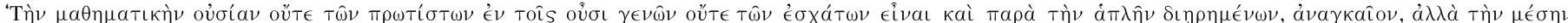

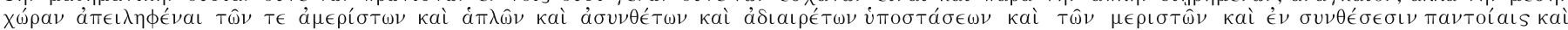

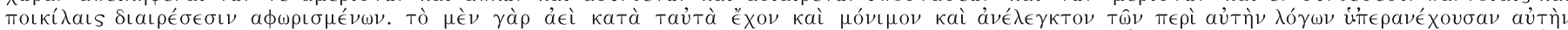

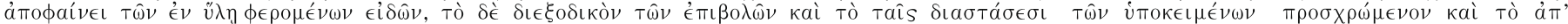

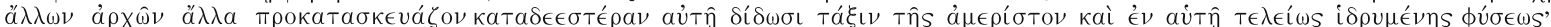

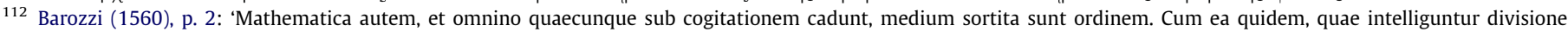

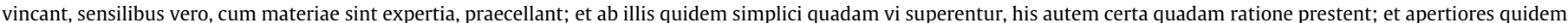

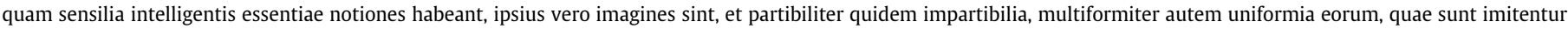

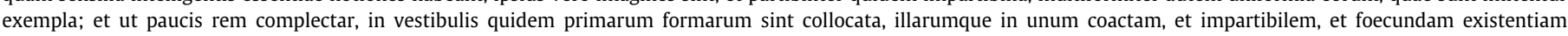

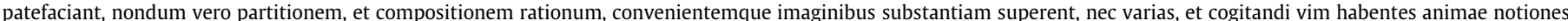

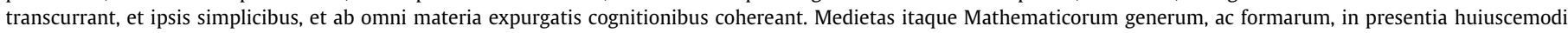

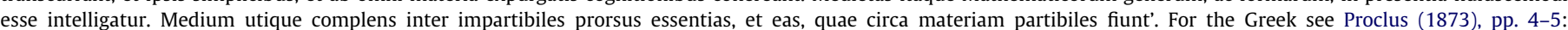

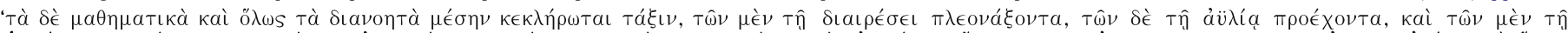

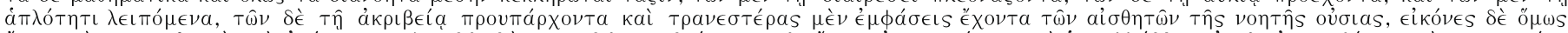

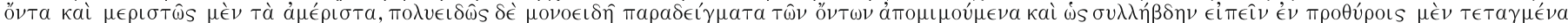

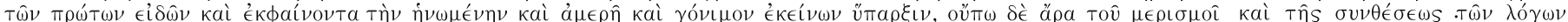

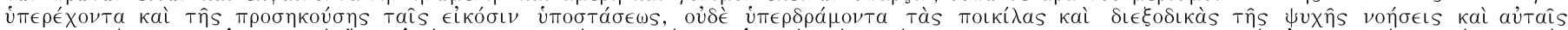

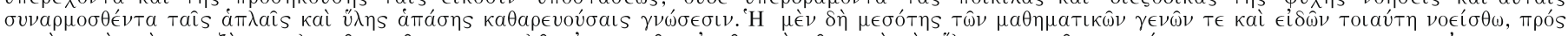

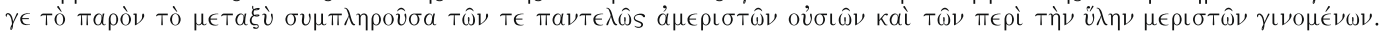


middle place where Patrizi locates mathematics is closer to what we find in Proclus than to Aristotle, whom Patrizi constantly and explicitly criticizes. But Patrizi, while being to some extent influenced by Proclus, is focused on the concept of space which is, through its unique and special features, the reason for this specific place of mathematics. Corporeality and incorporeality are Patrizi's main terms, through which he characterizes space and locates mathematics in the middle of these two ontological possibilities as the science of space. We do not find in Patrizi in this context any mention of essences or signs of a developed Neoplatonic metaphysical system as we do in Proclus. The great Neoplatonic philosopher, on the other hand, discusses here the essence of mathematics, and the emphasis in his discussion is on its middle place between indivisible and divisible substances (and indeed, we find here the common contrast between divisible, material, and sensible level, and immaterial, indivisible, and intelligible level). Although the immateriality of mathematics in Proclus corresponds to its incorporeality in Patrizi, their reasons, explanations, and conceptual framework as a whole are considerably different. It is true that, as we have seen, the notion of space as a body comes from Proclus; but the systematical and consistent development of this notion and its physical and mathematical implications outside the Aristotelian categories are Patrizi's. This is a good example of how a Renaissance philosopher works with his sources: a careful reading of sources exercises some influence, but also, in the case of Patrizi, provokes creativity and originality.

Thus, after showing the essential importance of geometry, on a purely philosophical level and without mentioning any authorities, Patrizi can remind his readers, on a rhetorical level, of the famous inscription at the entrance of Plato's Academy, and of a Pythagorean dictum ('everything was created from finite and infinite'), to which he adds that this saying should be understood with regard to the first space. ${ }^{113} \mathrm{He}$ immediately moves on to present a comparison between geometry and arithmetic, starting with the common elements, and then mentioning the specific features of each science, and what each of them gives to the other. ${ }^{114}$ Patrizi's final accord in his discussion of mathematical space is listing the names of useful sciences which originated from geometry and arithmetic, ${ }^{115}$ in order to refute Aristotle's argument that mathematics is useless in regard to human life, while emphasizing again that space is the source of mathematics. ${ }^{116}$

The relatively rare words, terms, and phrases used by Patrizi in his discussion of space (such as formatrix, ratio sensata, renitentia, fabrefactus, aptitudo, extensio hypostatica) do not indicate or reveal, in most cases, his direct sources, but rather his originality. They show that he tried to bring to the fore a new scientific terminology which should replace the common Aristotelian one. Since the contemporary scientific discourse was identified with, and determined by, Aristotelian terms and assumptions, it was essential for Patrizi to offer his readers an alternative terminology with which he presented his own scientific novel point of view, taking into account the tensions he found in the ancient sources with regard to the concept of space, and using mainly some Stoic and Neoplatonic ideas and developing, under some influence of Proclus' commentary on Euclid, a geometrical cosmos in his critique of Aristotle's physics. ${ }^{117}$ Patrizi's awareness of the importance of different ways of presentation and persuasion, of rhetoric and dialectic in the scien- tific discourse, and of terminology which determines this discourse, came directly from the humanists and the new humanistic methods and disciplines which were included under phrases like artes sermonales and studia humanitatis. Patrizi's notion of space (either physical or mathematical) contains two meanings, which correspond to the ontological and the epistemological levels. On the ontological level it is space in the technical sense; but on a more general and less technical sense which is found in Patrizi, indeed on the epistemological level, it should be interpreted as discourse. And thus, I contend, it is also possible to translate the titles of these books as 'The physical discourse' and 'The mathematical discourse'. In this respect, Francesco Patrizi is a very good case of a humanist philosopher.

\section{Acknowledgements}

The research for this study has been sponsored by the project Proclus' Commentary on Euclid's Elements: A Platonic Philosophy of Mathematics (funded by FWO-Flanders), which is taking place at the De Wulf-Mansion Centre for Ancient, Medieval, and Renaissance Philosophy, Institute of Philosophy, Catholic University of Louvain, and promoted by Professor Gerd Van Riel. I would like to thank Professor Van Riel for his support. I would also want to thank Professor M. W. F. Stone and Dr Luc Deitz for their helpful comments.

\section{References}

Algra, K. (1995). Concepts of space in Greek thought. Leiden: Brill.

Arnim, H. F. A. von. (Ed.). (1964). Stoicorum veterum fragmenta (4 vols.) (Vol. 4, M. Adler, Ed.). Stuttgart: Teubner. (First published Leipzig, 1903)

Barozzi, F. (1560). Procli Diadochi Lycii, commentariorum in primum Euclidis elementorum. Padova: Gratiosus Perchacinus.

Bianchi, L. (2003). Studi sull'Aristotelismo del rinascimento. Padova: Il Poligrafo.

Bianchi, L. (2007). Continuity and change in the Aristotelian tradition. In J. Hankins (Ed.), The Cambridge companion to Renaissance philosophy (pp. 49-71). Cambridge: Cambridge University Press.

(pseudo)-Boethius. (1867). Geometria. In G. Friedlein (Ed.), Anicii Manlii Torquati Severini Boetii de institutione arithmetica libri duo, de institutione musica libri quinque. Accedit geometria quae fertur Boetii. Leipzig: Teubner.

Bossier, F., \& Brama, J. (Eds.). (1990). Physica: Translatio vetus. Leiden: Brill.

Brickman, B. (1941). An introduction to Francesco Patrizi's Nova de universis philosophia. Ph.D. thesis, Columbia University.

Cao, G. M. (2001). The prehistory of modern scepticism: Sextus Empiricus in fifteenth-century Italy. Journal of the Warburg and Courtauld Institutes, LXIV, 229-279.

Copenhaver, B. P., \& Schmitt, C. B. (Eds.). (1992). Renaissance philosophy. Oxford: Oxford University Press.

Cranz, F. E., \& Schmitt, C. B. (Eds.). (1984). A bibliography of Aristotle editions 15011600. Baden-Baden: Verlag Valentin Koerner.

Deitz, L. (1999). Space, light, and soul in Francesco Patrizi's Nova de universis philosophia (1591). In A. Grafton, \& N. Siraisi (Eds.), Natural particulars. Nature and the disciplines in Renaissance Europe (pp. 139-169). Cambridge, MA: MIT Press.

Deitz, L. (2007). Francesco Patrizi da Cherso's criticism of Aristotle's logic. Vivarium, $45,113-124$.

Diels, H. (Ed.). (1882). Simplicii in Aristotelis physicorum libros quattuor priores commentaria. In idem, Commentaria in Aristotelem Graeca (23 vols.) (Vol. 9, pp. 601-645). Berlin: Walter de Gruyter.

Diels, H., \& Kranz, W. (Eds.). (1969). Die Fragmente der Vorsokratiker. Dublin: Weidmann. (First published Berlin, 1903)

Edelstein, L., \& Kidd, I. G. (Eds.). (1972). Posidonius. Cambridge: Cambridge University Press.

Ficino, M. (2001-2006). Theologia platonica de immortalitate animorum (6 vols.) (J. Hankins, with W. Bowen, Eds.; M. J. B. Allen, with J. Warden, Trans.). Cambridge, MA: Harvard University Press.

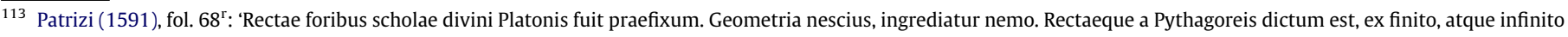
omnia ortum habuisse, quando de spacio primo id intellexisse comperiantur'.

114 Ibid., fol. $68^{\mathrm{v}}$.

115 Ibid.

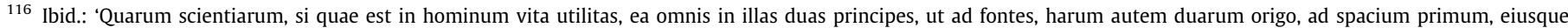
scientiam hisce libris a nobis omnium primis exaratam est referenda. Unde falsam fuisse apparet Aristotelis assertionem, qui mathematicas fine, et utilitate carere docuit'.

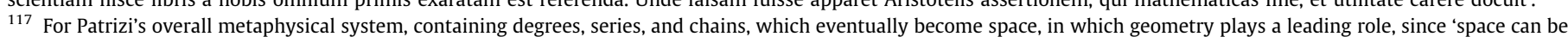

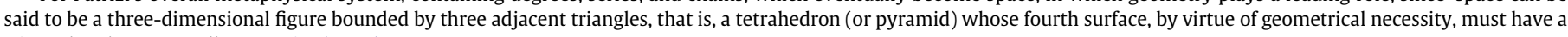
triangular shape as well', see Deitz (1999), p. 143.
} 
Floridi, L. (2002). Sextus Empiricus-The transmission and recovery of Pyrrhonism. Oxford: Oxford University Press.

Garber, D. (1995). J.-B. Morin and the second objections. In R. Ariew, \& M. Grene (Eds.), Descartes and his contemporaries. Meditations, objections, and replies ( $\mathrm{pp}$. 63-82). Chicago: University of Chicago Press.

Gentile, S., \& Gilly, C. (Eds.). (1999). Marsilio Ficino e il ritorno di Ermete Trismegisto. Firenze: Centro Di.

Grant, E. (1981). Much ado about nothing: Theories of space and vacuum from the Middle Ages to the Scientific Revolution. Cambridge: Cambridge University Press.

Henry, J. (1977). Patrizi and the concept of space: His contribution to the development of the concept of void space and the infinite universe. M. Phil. dissertation, University of Leeds.

Henry, J. (1979). Francesco Patrizi da Cherso's concept of space and its later influence. Annals of Science, 36, 549-575.

Kirk, G. S., Raven, J. E., \& Schofield, M. (Eds.). (1957). The presocratic philosophers: A critical history with a selection of texts. Cambridge: Cambridge University Press.

Kraye, J. (2007). The revival of Hellenistic philosophies. In J. Hankins (Ed.), The Cambridge companion to Renaissance philosophy (pp. 97-112). Cambridge: Cambridge University Press.

Kristeller, P. O. (1966). Eight philosophers of the Italian Renaissance. Stanford: Stanford University Press.

Kristeller, P. O. (1993). Studies in Renaissance thought and letters, III. Roma: Edizioni di Storia e Letteratura.

Lohr, C. H. (1986). The Pseudo-Aristotelian Liber de causis and Latin theories of science in the twelfth and thirteenth centuries. In J. Kraye, W. F. Ryan, \& C. B. Schmitt (Eds.), Pseudo-Aristotle in the Middle Ages (pp. 53-62). London: Warburg Institute.

Muccillo, M. (1986). Marsilio Ficino e Francesco Patrizi da Cherso. In G. C. Garfagnini (Ed.), Marsilio Ficino e il ritorno di Platone: studi e documenti (2 vols.) (Vol. 2, pp. 615-679). Firenze: L. S. Olschki.

Nock, A. D., \& Festugiere, A. J. (1954-1960). Corpus Hermeticum (4 vols.) (A. D. Nock, Ed.; A. J. Festugiere, Trans.). Paris: Société d'édition 'Les belles lettres'.

Patrizi, F. (1591). Nova de universis philosophia. Ferrara: Benedetto Mammarelli.

Patrizi, F. (1943). An English translation of Patrizi's book on physical space, and excerpts of his book on mathematical space by Benjamin Brickman. Journal of the History of Ideas, 4, 224-245.
Patrizi, F.(1996). De spacio physico et mathematico (H.Védrine, Ed. \& Trans.). Paris: Vrin. Proclus. (1864). In Platonis Parmenidem (V. Cousin, Ed.). Paris: Olms.

Proclus. (1873). In primum Euclidis elementorum librum commentarii (G. Friedlein, Ed.). Leipzig: Teubner.

Proclus. (1968-1997). Théologie platonicienne (6 vols.) (H. D. Saffrey, \& L. G. Westerink, Eds. \& Trans.). Paris: Budé.

Schabel, C. (2000). Place, space, and the physics of grace in Auriol's sentences commentary. Vivarium, 38(1), 117-161.

Schmidt-Biggemann, W. (2004). Philosophia perennis: Historical outlines of Western spirituality in ancient, medieval, and early modern thought. Dordrecht: Springer.

Schmitt, C. B. (1966). Perennial philosophy: From Agostino Steuco to Leibniz. Journal of the History of Ideas, XXVII, 505-532.

Schmitt, C. B. (1970). Prisca theologia e Philosophia perennis: due temi del Rinascimento italiano e la loro fortuna. In G. Tarugi (Ed.), Il pensiero italiano del Rinascimento e il tempo nostro (pp. 211-236). Firenze: L. S. Olschki.

Schmitt, C. B. (1981). Studies in Renaissance philosophy and science. London: Variorum Reprints.

Schmitt, C. B. (1983). Aristotle and the Renaissance. Cambridge, MA: Harvard University Press.

Schmitt, C. B. (1984). The Aristotelian tradition and Renaissance universities. London: Variorum Reprints.

Sorabji, R. (1987). John Philoponus. In R. Sorabji (Ed.), Philoponus and the rejection of Aristotelian science (pp. 1-40). Cornell: Cornell University Press.

Todd, R. B. (1982). A note on Francesco Patrizi's use of Cleomedes. Annals of Science, 39, 311-314.

Tummers, P. M. J. E. (1980). Geometry and theology in the XIIIth century: An example of their interrelation as found in the Ms Admont 442. The influence of William of Auxerre? Vivarium, 18(2), 112-142.

Vasoli, C. (2002). Le filosofie del Rinascimento. Milano: Bruno Mondadori.

Vasoli, C. (2007). La critica di Francesco Patrizi alla dottrina aristotelica degli elementi: Il fuoco, l'aria e l'acqua. Rinascimento, XLVII, 93-106.

Walker, D. P. (1972). The ancient theology: Studies in Christian Platonism from the fifteenth to the eighteenth century. Ithaca: Cornell University Press.

Yates, F. A. (1964). Giordano Bruno and the hermetic tradition. Chicago: University of Chicago Press. 